ص ص[ب-r

مستوى التفكير الاستر اتيجي لاى قادة المنظمات الأهلية في قطاع غزة لأني

الدكتور ماجد محمد الفرا

أستاذ مشارك- - قسم إدارة الأعمال محدال

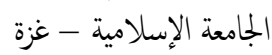

melfarra@iugaza.edu.ps

\begin{abstract}
المستخلص
تهذف هذه الدراسة إلى التعرف على مستوى التفكير الاستراتيجي للدى المنظمسات الأهلية

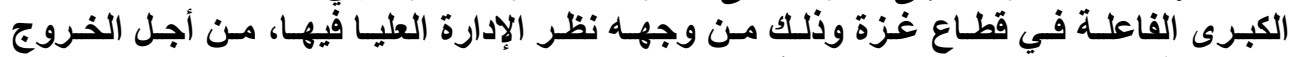

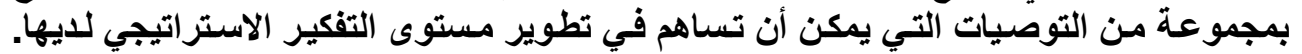

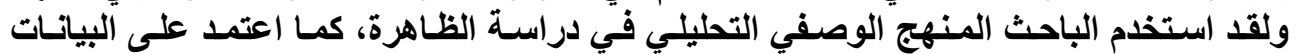

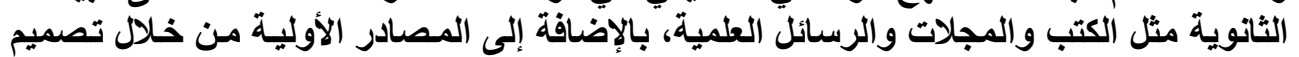

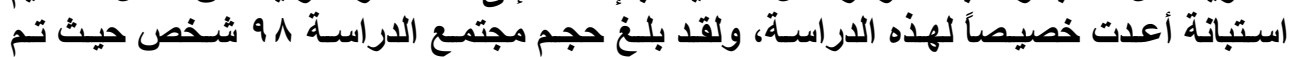

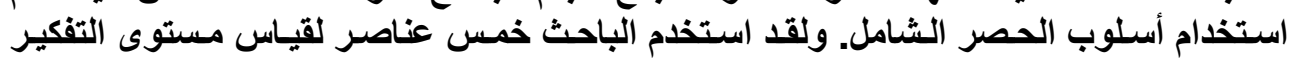

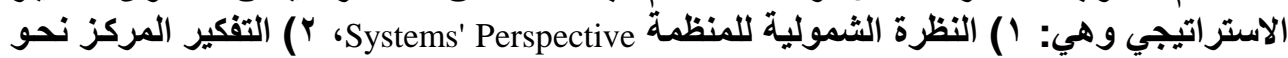

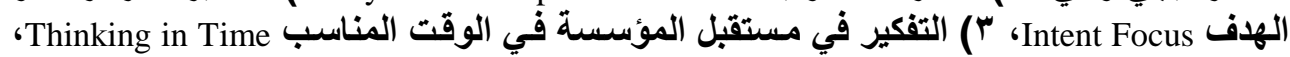

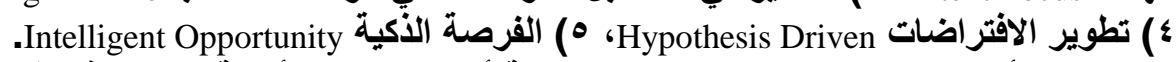

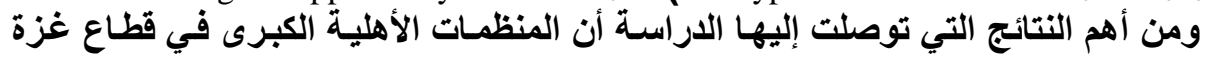

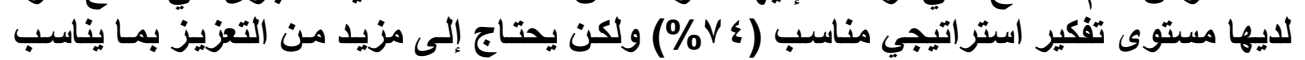

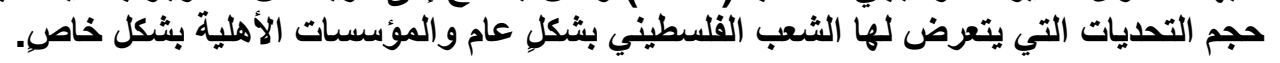


الدكتور الفرا [ـ[ب]

\title{
The Level of Strategic Thinking Among Non- Governmental Leaderships In Gaza Province
}

\author{
Majid M. Al-Farrah (PhD) \\ Associate Professor \\ Department of Business Administration \\ Islamic University - Gaza \\ melfarra@iugaza.edu.ps
}

\begin{abstract}
The study aims to identify the level of strategic thinking at the large non-governmental organization (NGOs) in the Gaza province. This was done to come up with some recommendations that may contribute in developing NGOs strategic thinking. The researcher used descriptive analytical approach. Both secondary and primary data were used. The secondary data included textbooks, journals and theses. The questionnaire was designed as a major tool to collect the primary data. The research population was 98 individual and the comprehensive survey was considered. The research used five factors to measure the level of strategic thinking. They included: 1. Intent Focus, 2. systems' perspective, 3. thinking in time, 4. hypothesis driven and 5. Intelligent opportunity. The main study concluded that the level of strategic thinking at Gaza's NGOs was suitable (74\%). However it needs further development to upgrade the NGOs capabilities to match the level of challenges the Palestinian people face in general and NGOs in particular.

المقدمة

يتصف عالم اليوم بالديناميكية و التغير السريع ويكاد ذللك يكون في كل شــئ

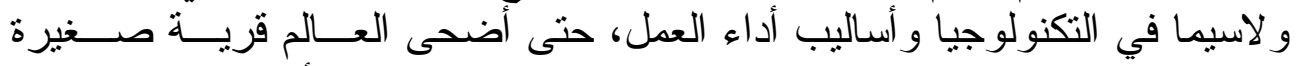

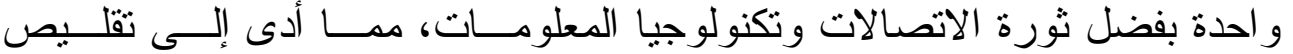

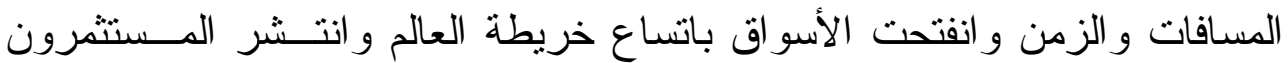
ورجال الأعمال و المسوقون أينما وجدت الفرصة للاستثمار و اشتثت حدة المنافسة (Wheelen and Hunger, 2006) بروز الحاجة إلى تطبيق الفكر الاستر اتيجي في المؤسسات القائمة علــى التفكيــر

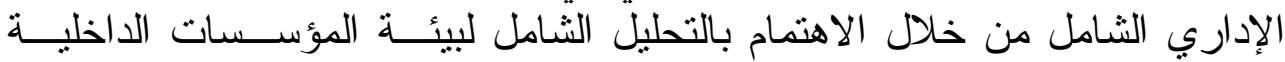

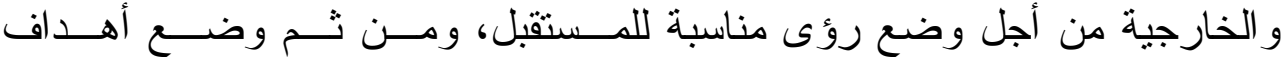

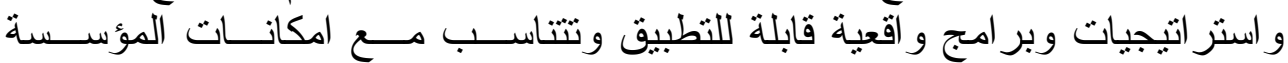
و أصحاب المصالح Bonn, 2005) Stakeholders).

وفي ضوء التغير ات المتلاحقة منذ بدء الانتفاضة الفلسطينية الثانية (انتفاضة

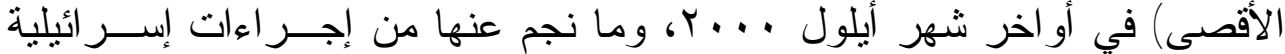

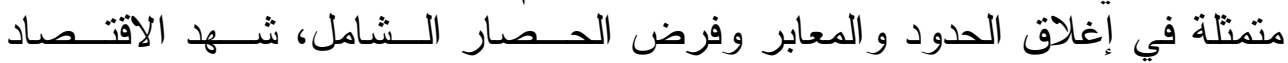

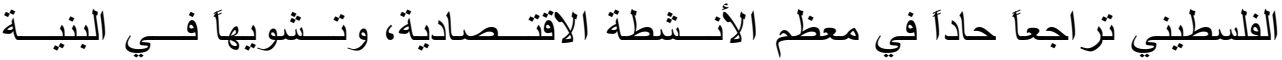

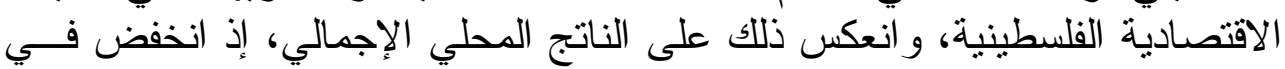




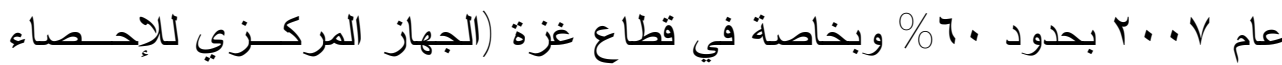

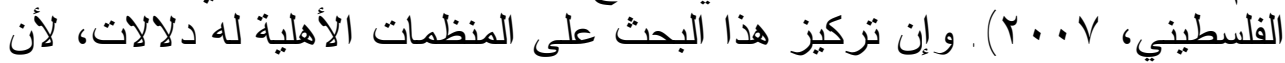

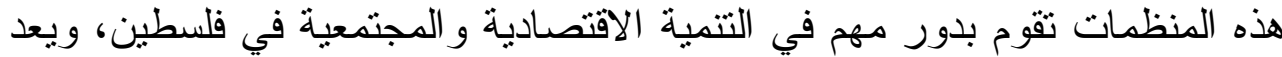

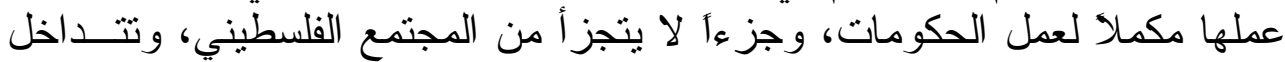

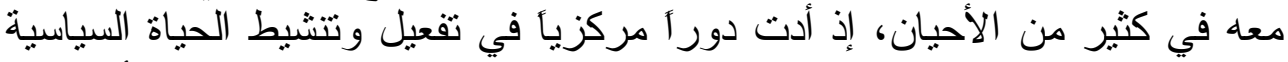

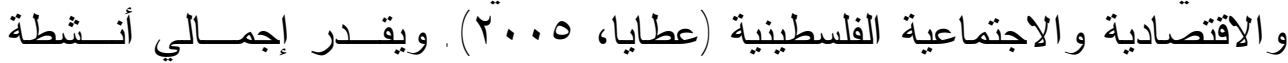

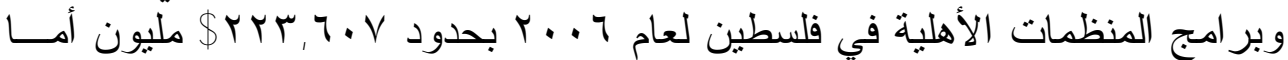

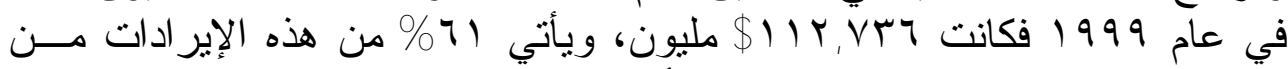

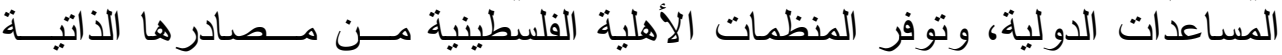
1,0

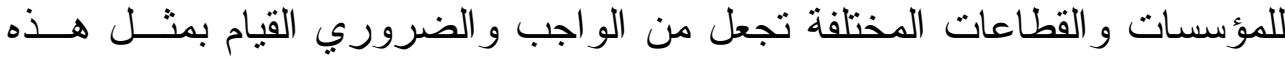

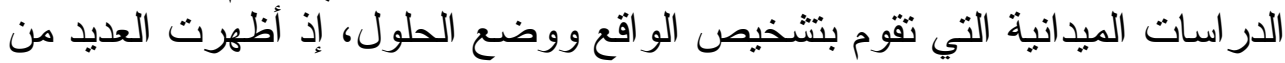

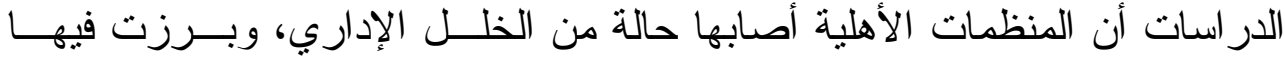

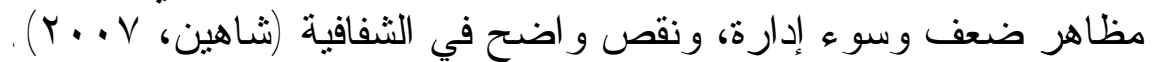

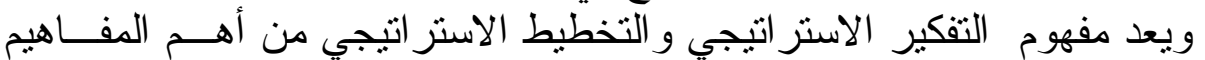

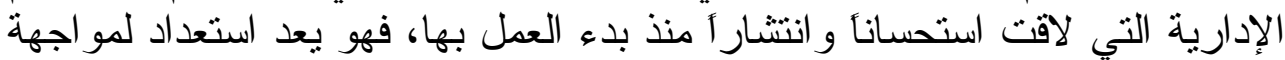

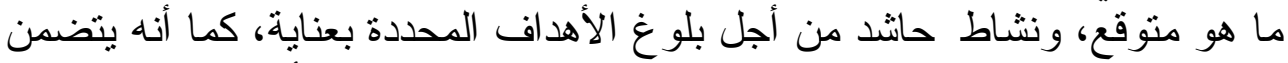

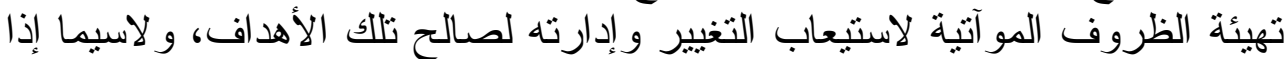

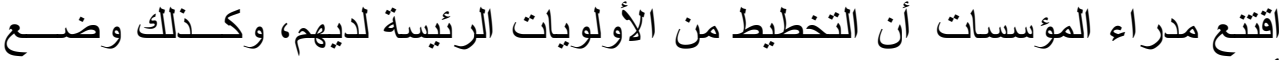

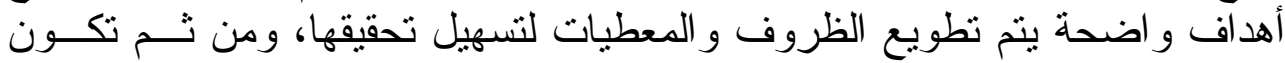

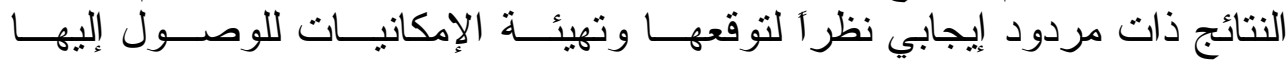
.(Thompson and Strickland, 1999)

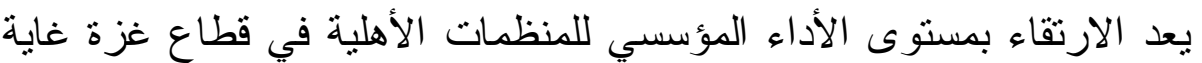

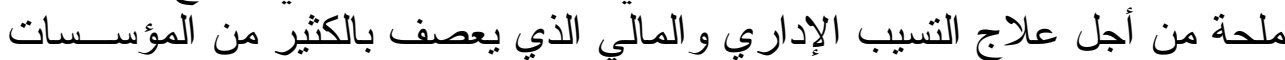

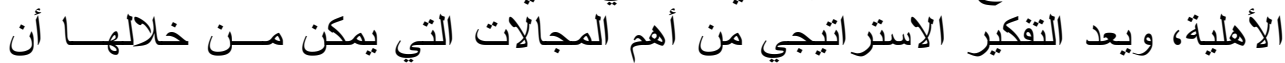

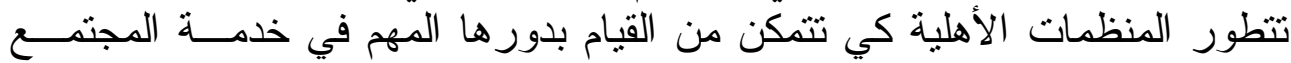

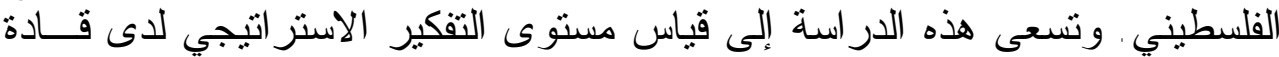

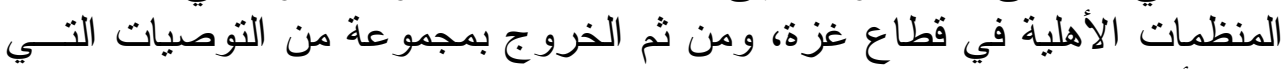

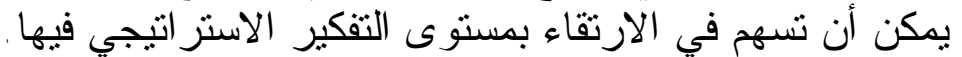

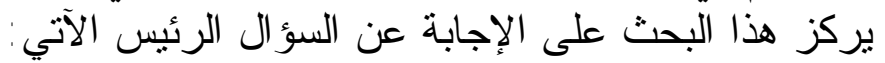
ما مستوى التفكير الاستر اتيجي لدى قادة المنظمات الأهلية في قطاع غزة الأب؛ 
فرضيات الار اسة

تتمثل فرضيات الدراسة في الفرضية الرئيسة الآتية:

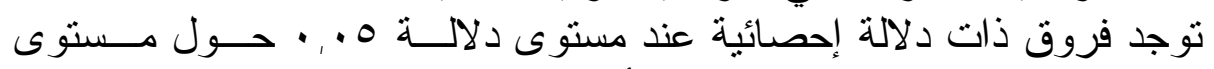

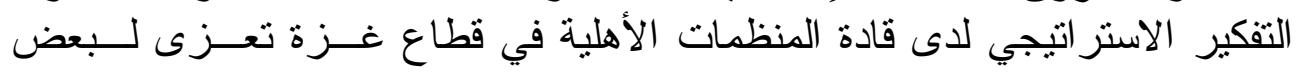

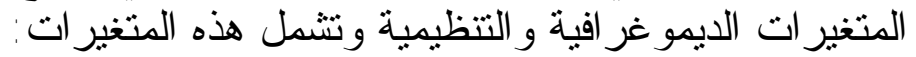

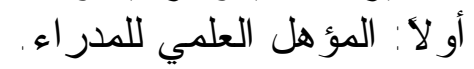

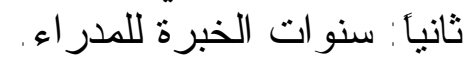

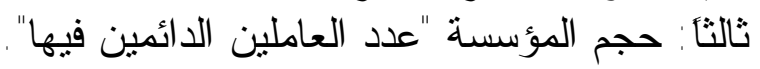

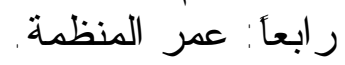

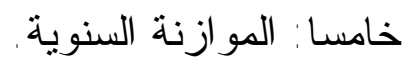

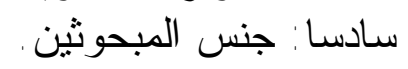

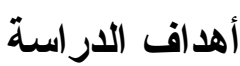
تسعى هذه الدر اسة إلى تحقيق الأهداف الآتية:

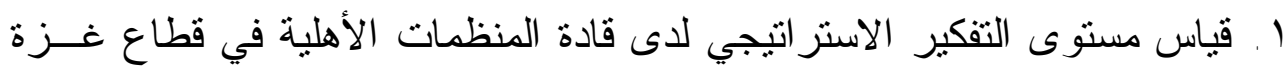

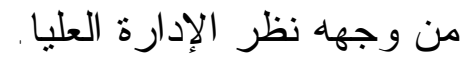

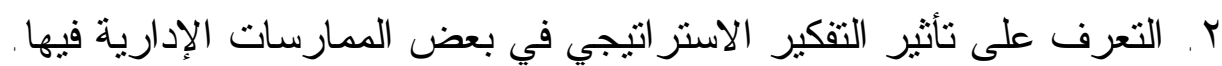

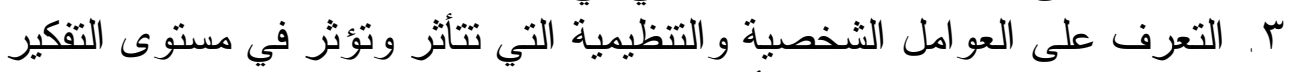
الاستر اتيجي في المؤسسات الأهلية.

\section{أهمية الاراسة}

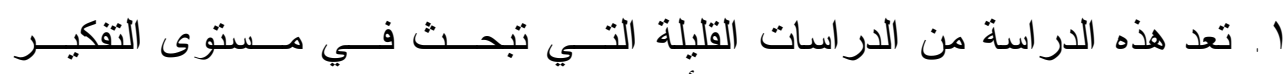

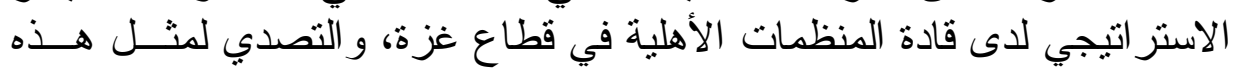

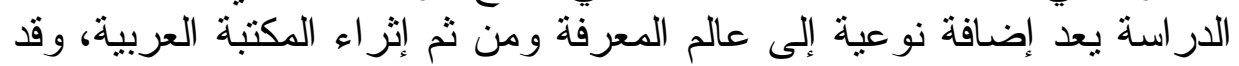

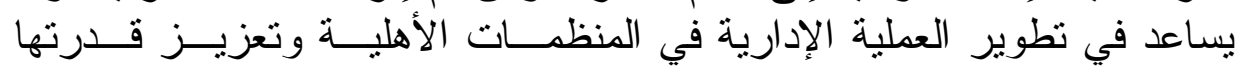
النتافسية.

r. وتظهر أهمية هذه الدراسة في استتادها إلى المصادر الأولية من خلال استخدام

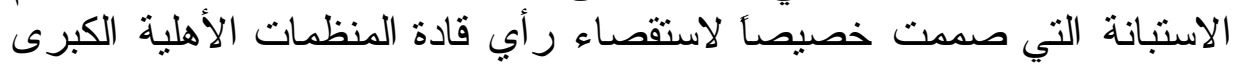

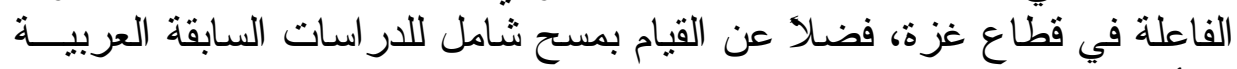

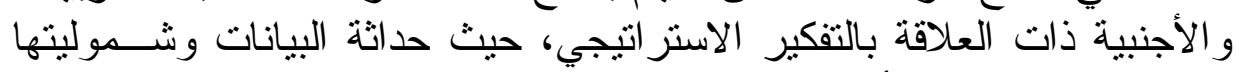

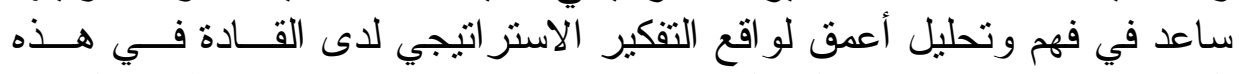

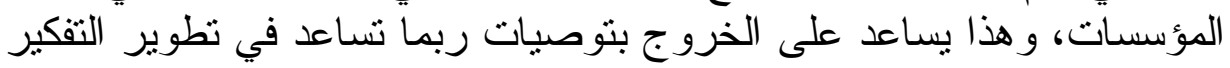
الاستر اتيجي لاى قادة المنظمات في قطاع غزة بترة 


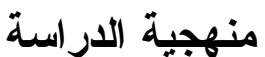

تم استخدام المنهج الوصفي التحليلي للوصول إلى المعرفة الدقيقة والتفصيلية

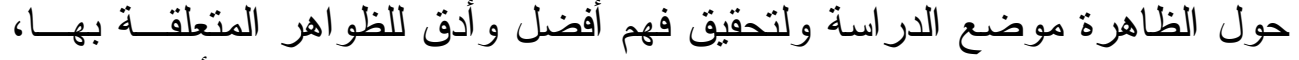

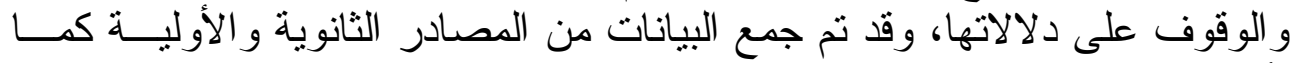

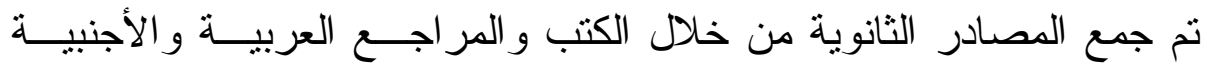

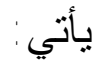

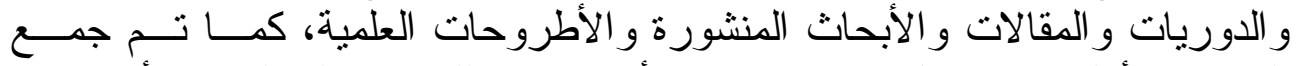

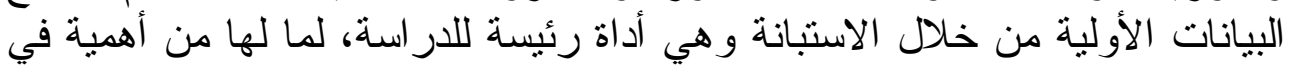

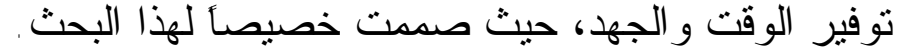

\section{مجتمع الار اسة و وعينها}

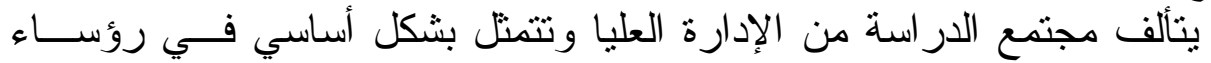

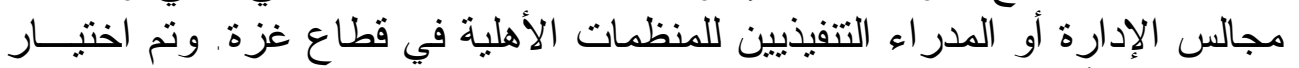

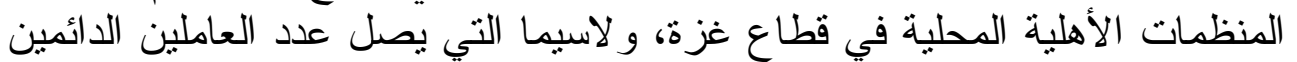

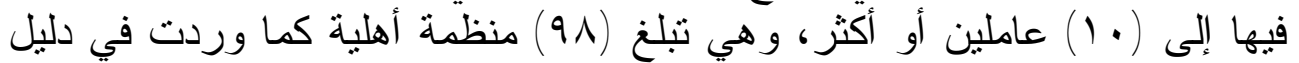

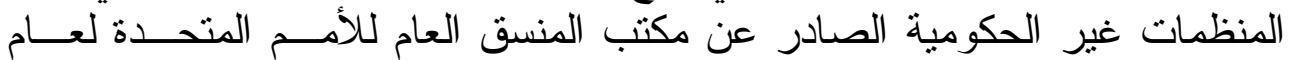

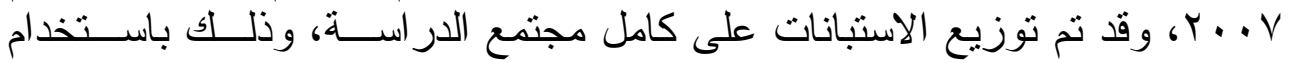

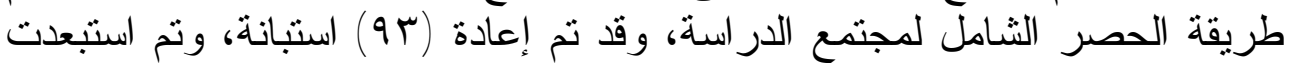

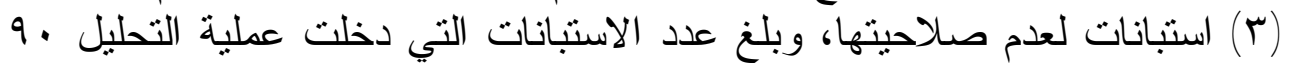

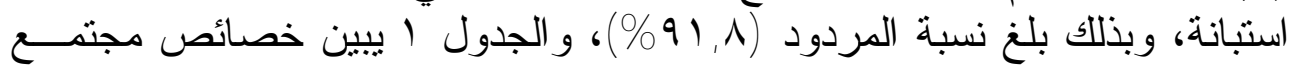

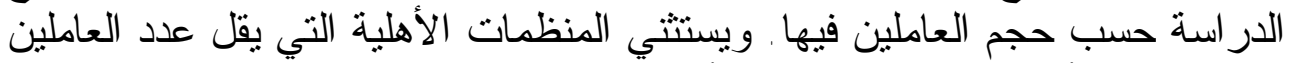

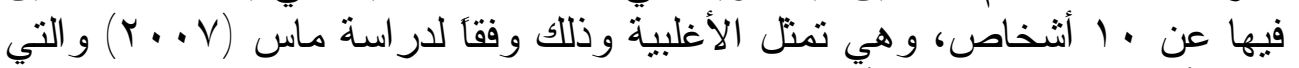

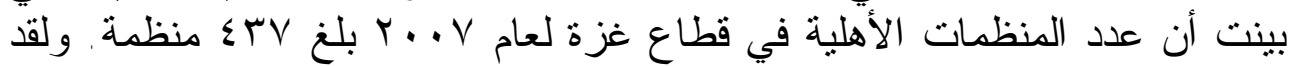

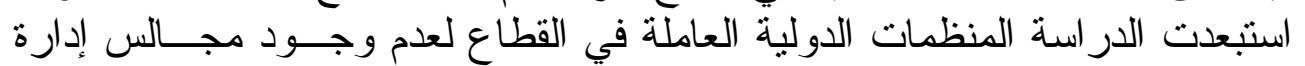
محلية لها و لاختلاف فلسفة ونمط الإدارة فيها.

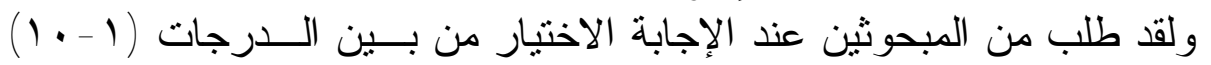

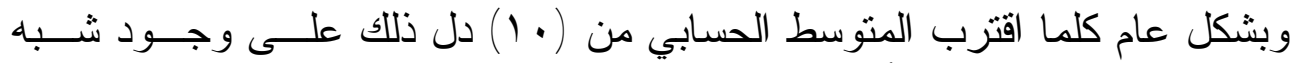

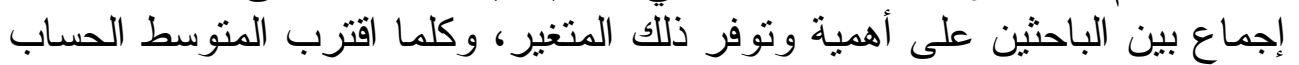

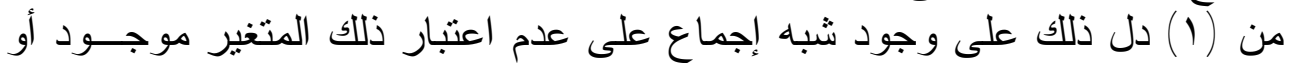

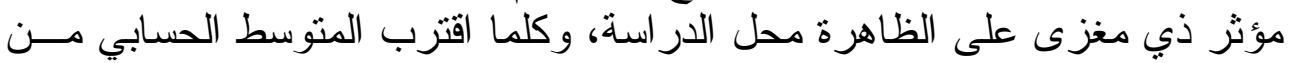

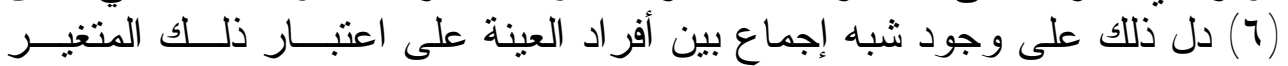
منوسط الأهمية أو محايد. 


\begin{tabular}{|c|c|}
\hline عدد المنظمات & تصنيف المنظمات الأهلية حسب عدد العاملين \\
\hline \&1 & . 1 - . . موظف \\
\hline ro & $0 .-Y_{1}$ \\
\hline it & $1 \ldots 01$ \\
\hline 1 . & أكثز من . 1 \\
\hline 91 منظمة & الإجمالي \\
\hline
\end{tabular}

\section{صدق الاستبانة وثباتها \\ تم التحقق من صدق الاستبانة بعدة طر ائق منها:

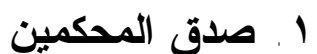

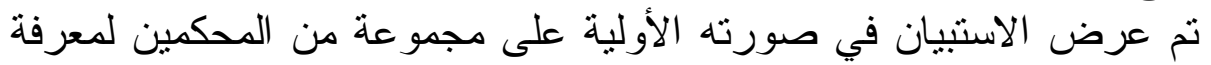

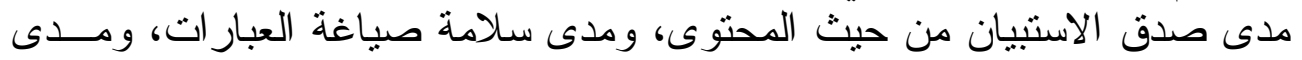

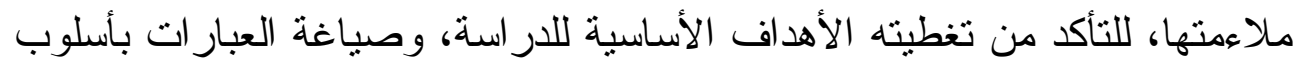

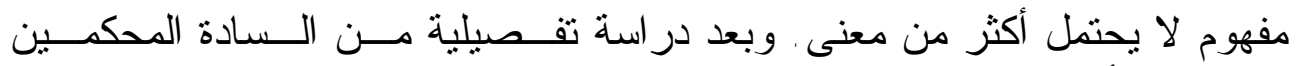

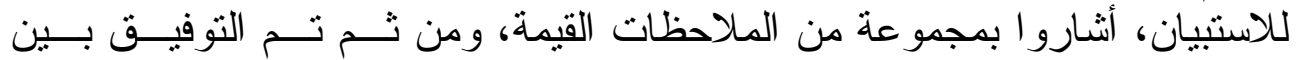

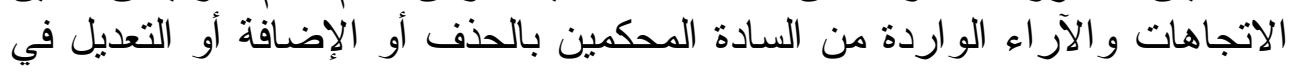

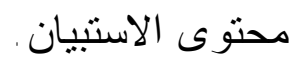

r الداسة الاستطلاعية

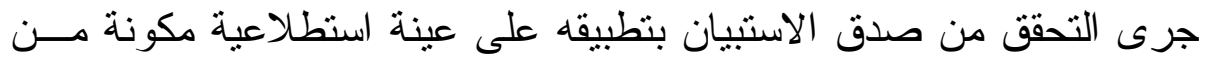

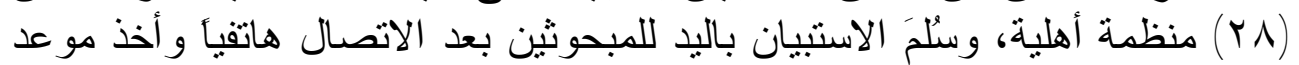

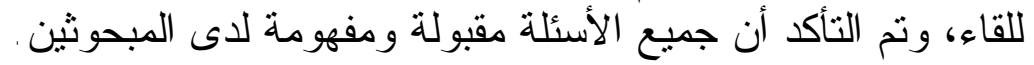

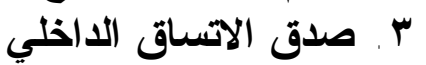

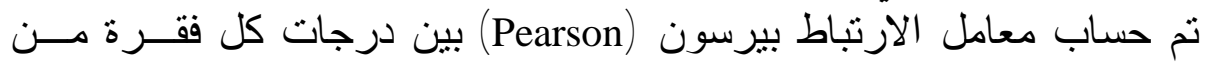

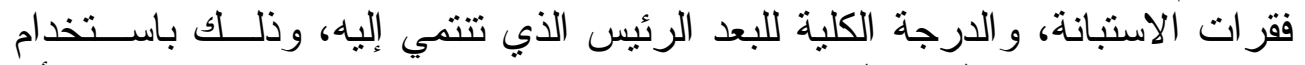

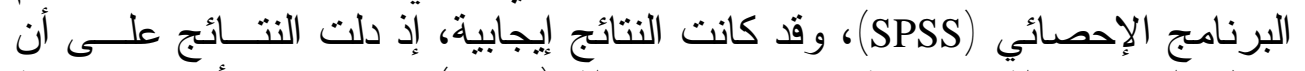

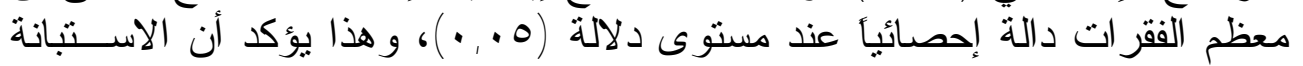
تتمتع بدرجة عالية من الاتساق الداخلي يطمئن إلى أنها صالحة للنطبيق على على عينة

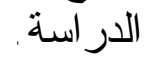


ع ـ ثبات الاستبانة

تم تقدير ثبات الاسنبانة على أفر اد العينة الاسنطلاعية وذلك باستخدام طريقتي

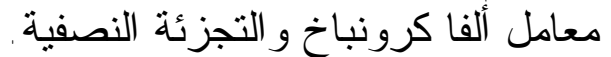

أ. التجزئة النصفية الفرونياخ

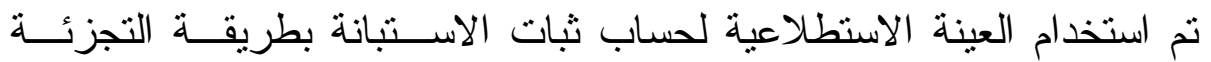

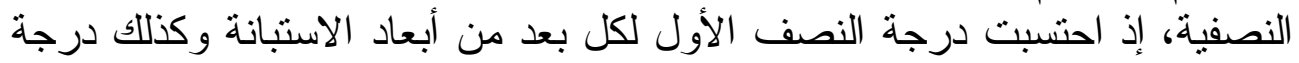

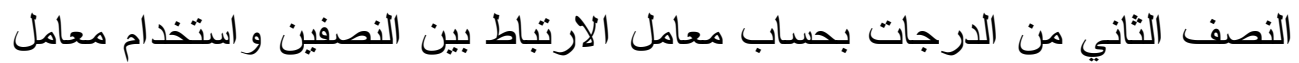

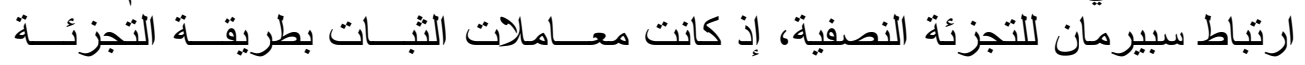

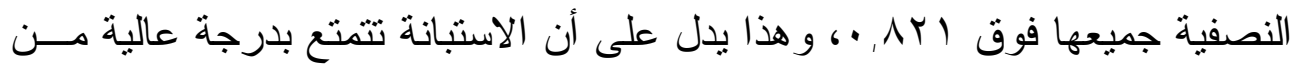
الثبات .

ب. اختبار ألفا كرونباخ

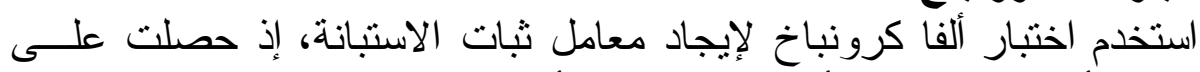

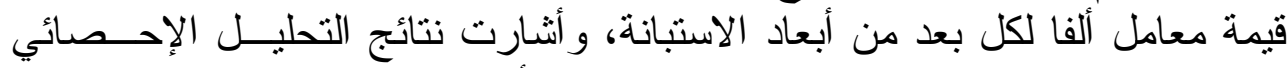

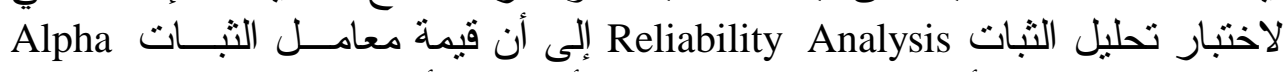
Coefficient عالية من الثبات.

\section{الأساليب الإحصائية المستخدمة في الاراسة}

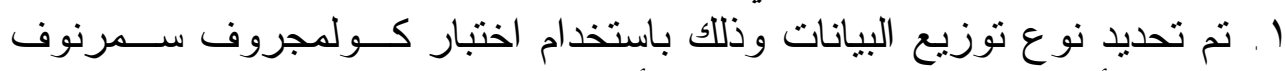

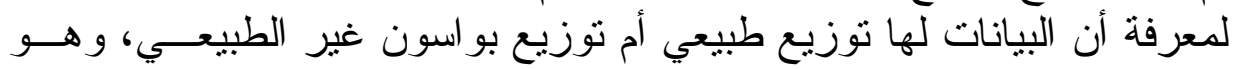

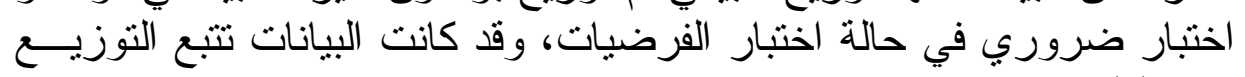

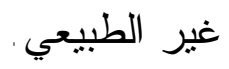

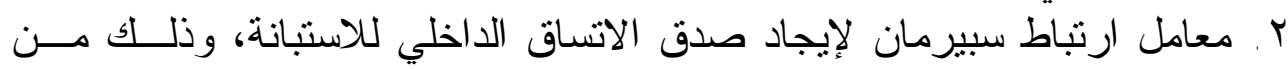

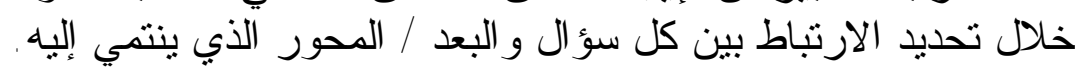

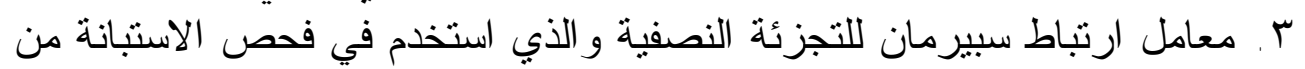

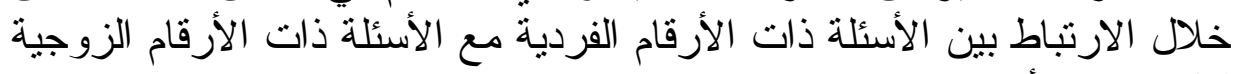

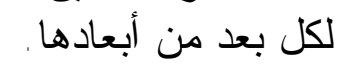
ع. معامل ارتباط ألفا كرونباخ لإيجاد معامل ثبات الاستبانة .

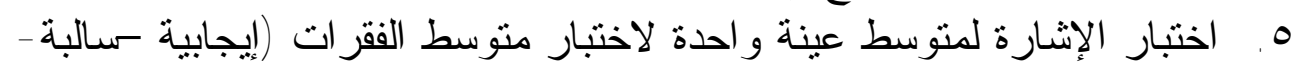
محايدة) . 7 ـ التكر ار ات و النسب المئوية و المتوسطات الحسابية و الوزن النسبي.

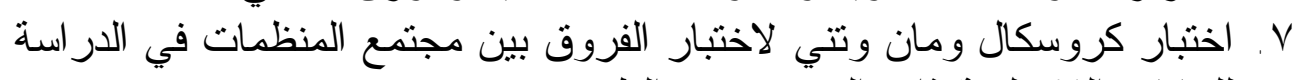

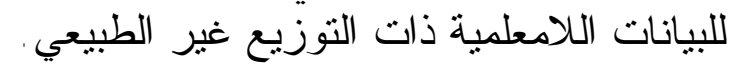




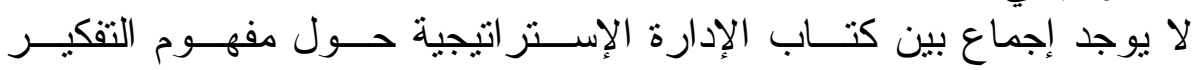

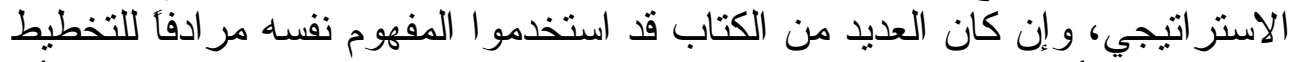

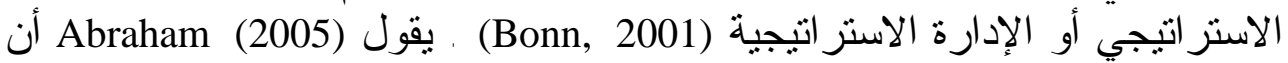

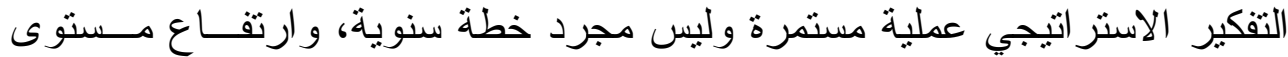

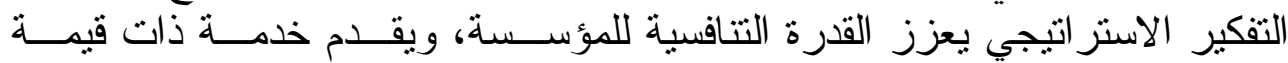

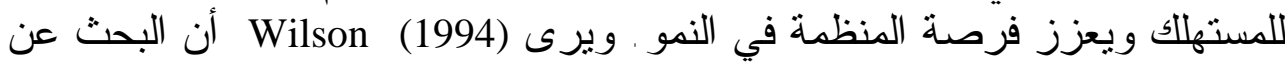

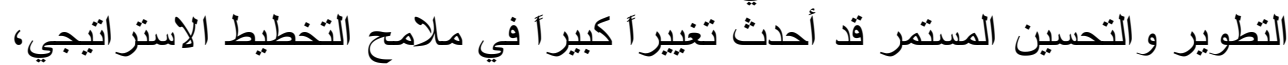

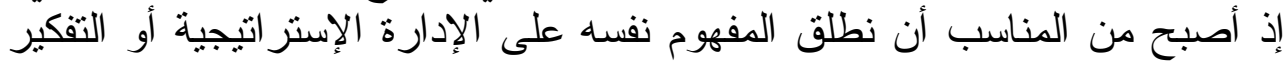

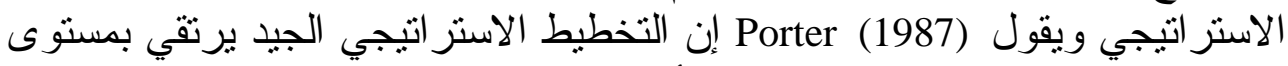

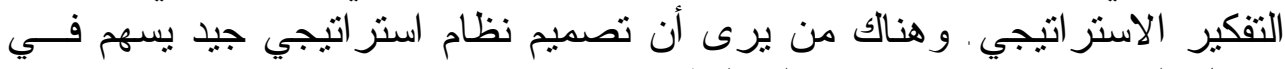

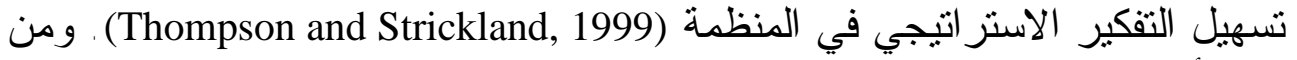

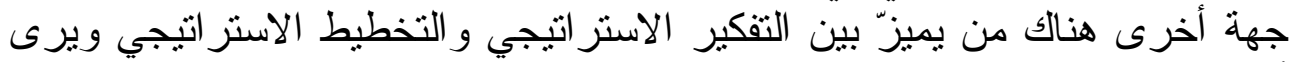

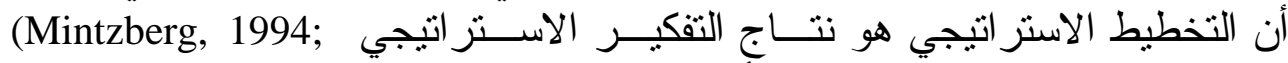

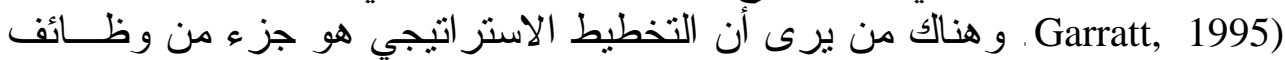

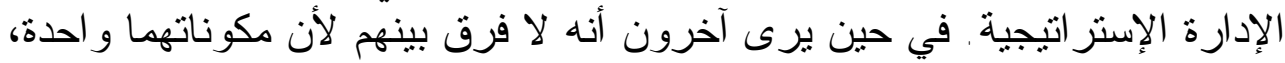

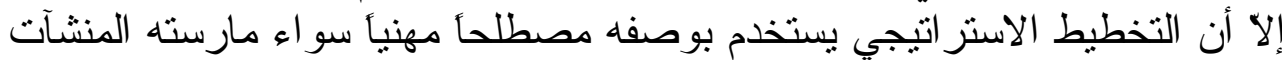

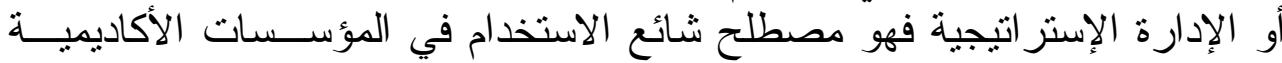
(David, 1999). و الإدارة الإستر اتيجية هي "خطة عمل تمكن المنظمة من الإنة الانتقال

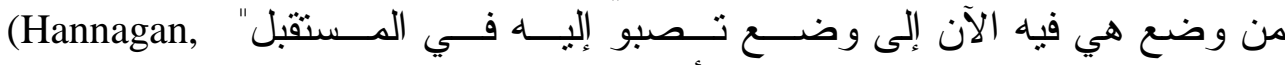

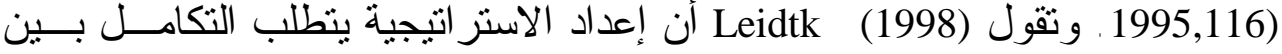

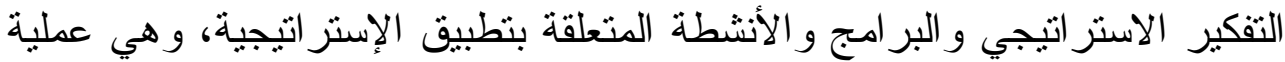

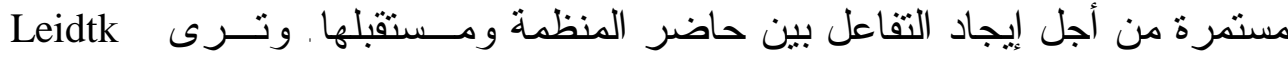

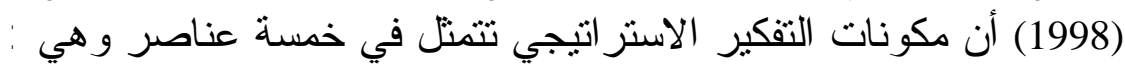

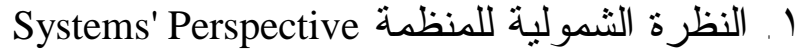

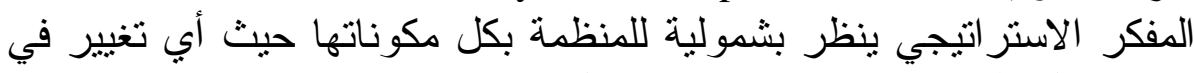
أي جانب في المنظمة يؤثر في كافة جو انب المؤئر المئسة

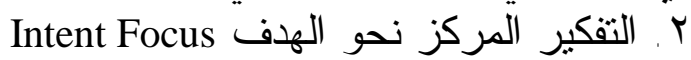

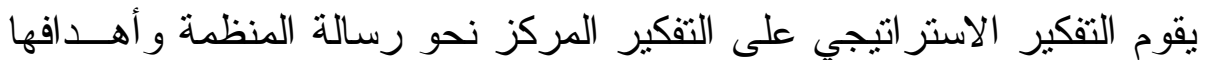

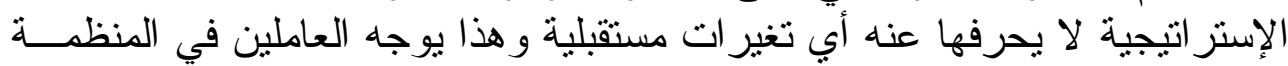
نحو النزكيز على تحقيق ذلك.

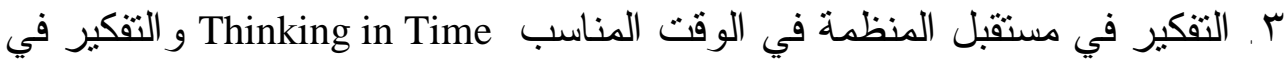
الوقت المناسب يقوم على فكرة معرفة المستقبل الذي نرغب في إيجاده، وليس 


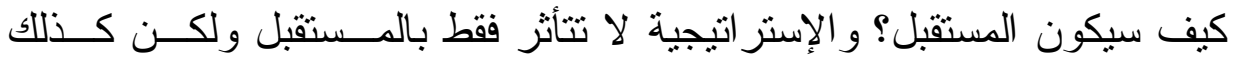

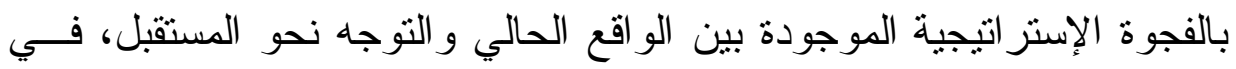

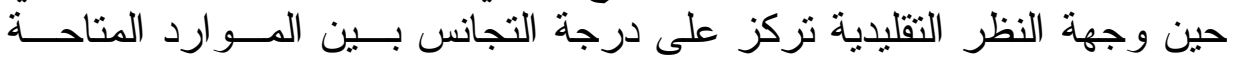
و الفرص المتاحة.

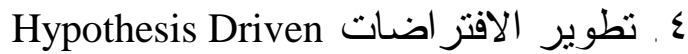

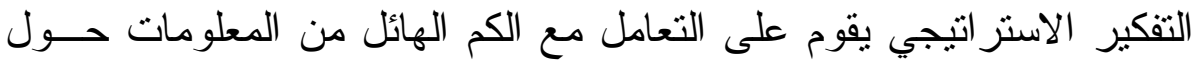

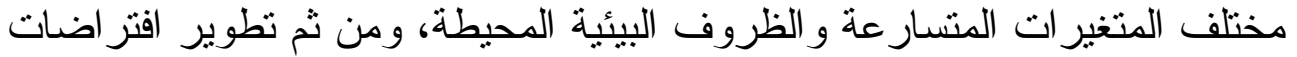

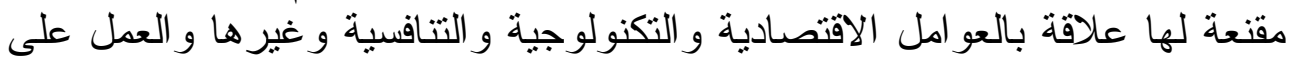

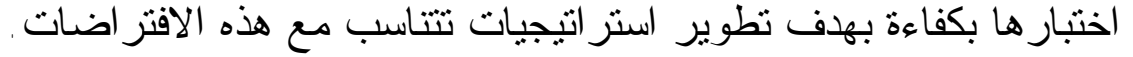

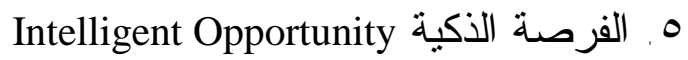

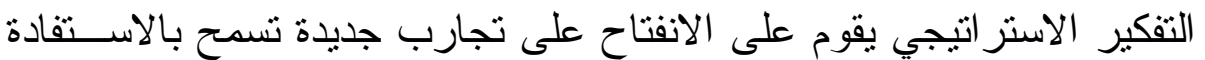

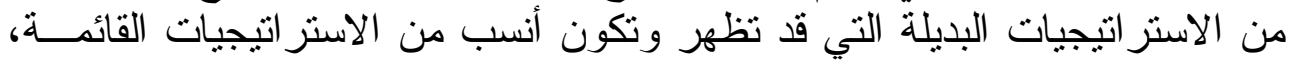

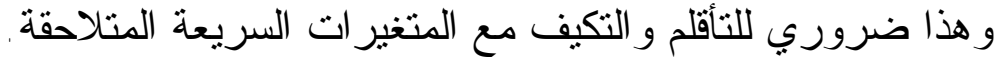

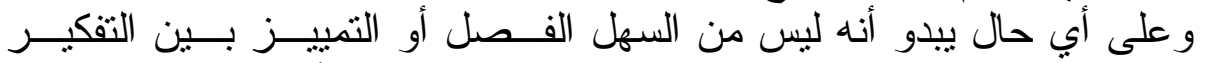
الاستر اتيجي و التخطيط الاستر اتيجي و الإدارة الاستر اتيجية، لأن الإدارة و التئي التخطيط

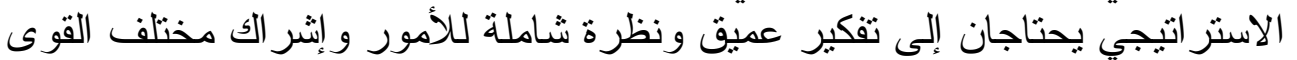

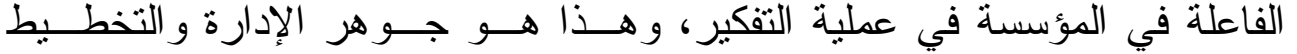

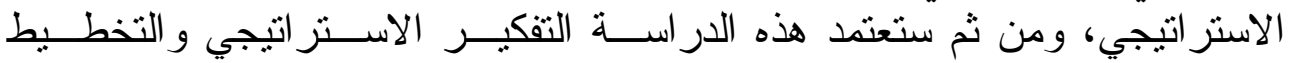

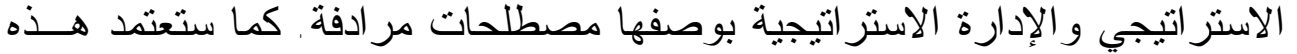

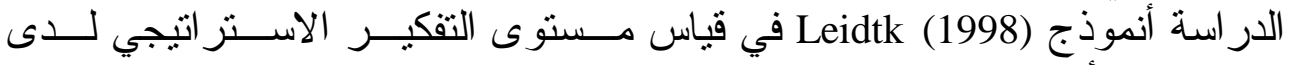
المنظمات الأهلية في قطاع غزة.

ثانياً - الار اسات السابقة

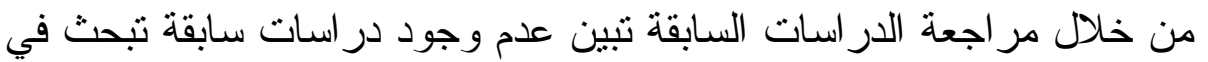

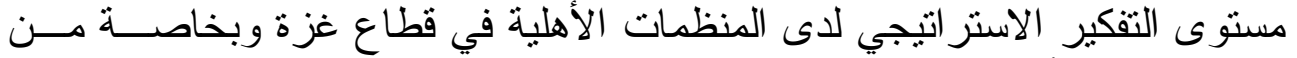

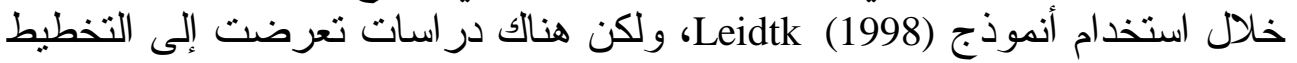
الاستر اتيجي في قطاعات مختلفة ومن هذه الدات الدر اسات ما يأتي:

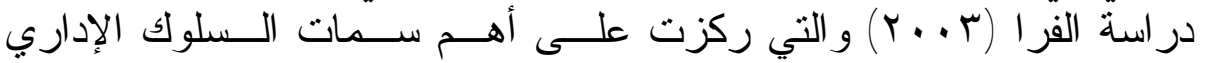

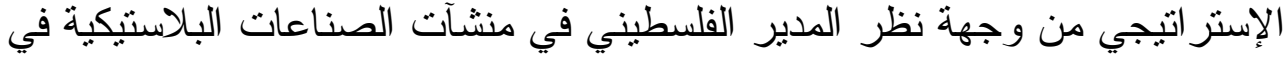

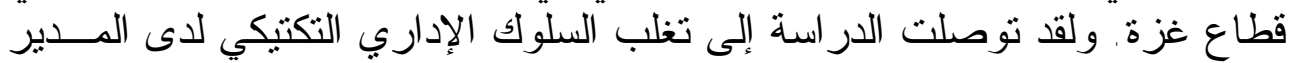

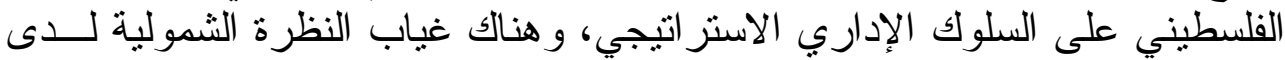

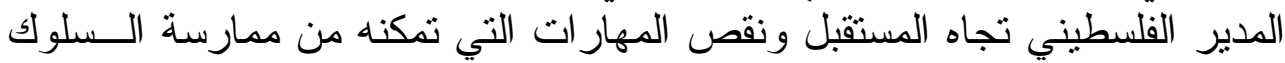

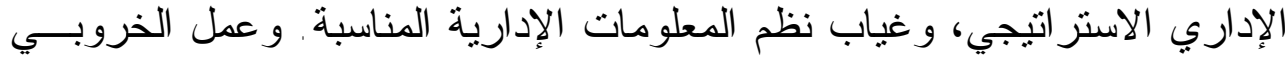

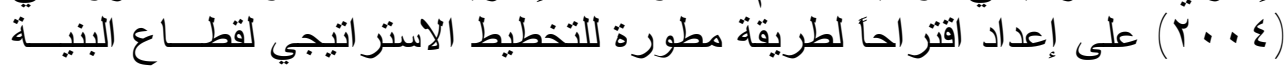

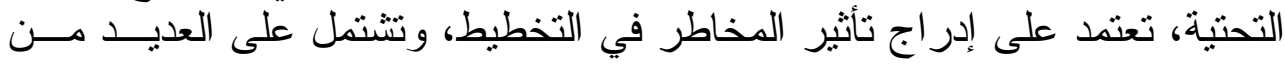


الخطوات التي تؤدي إلى حل المشاكل المتعلقة بقطاعات البنية التحتية في البلــــان

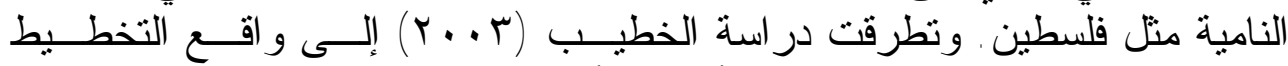

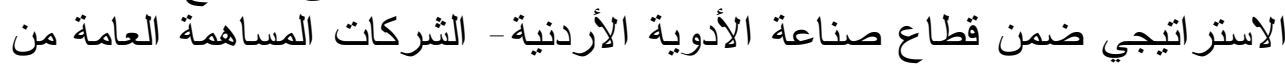

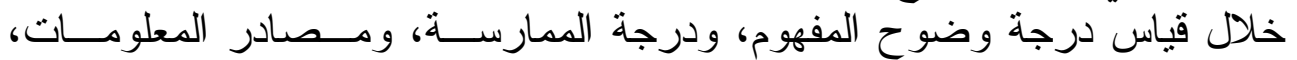

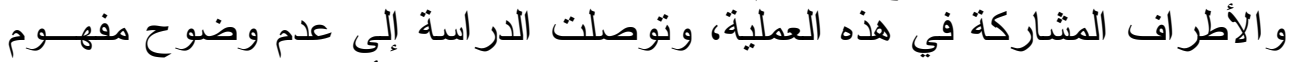

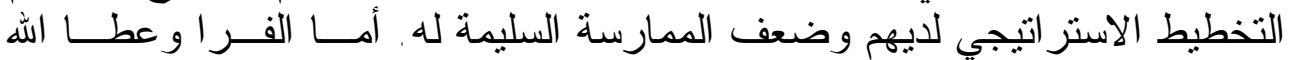

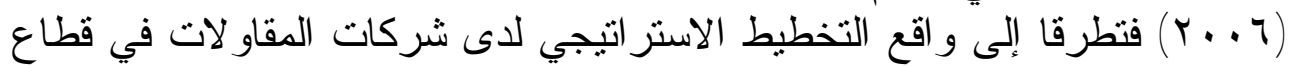

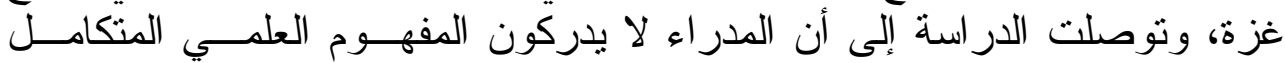

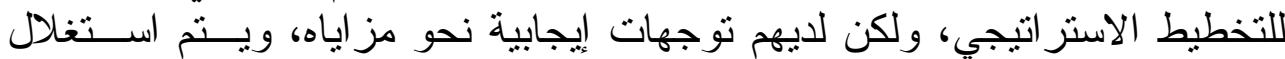

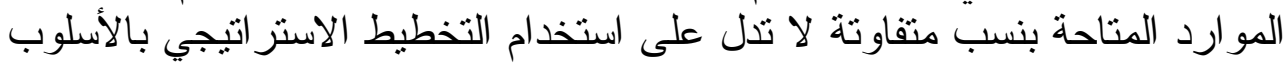

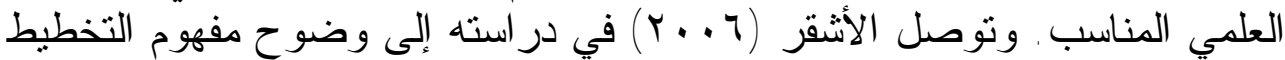

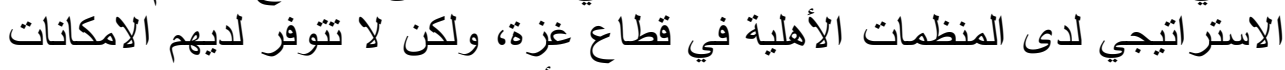

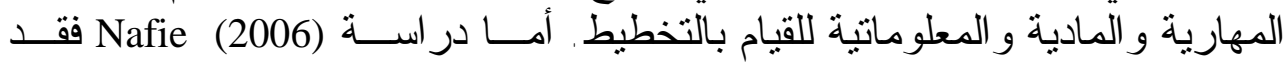

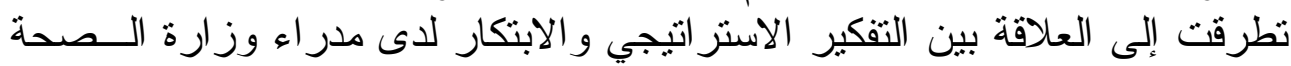

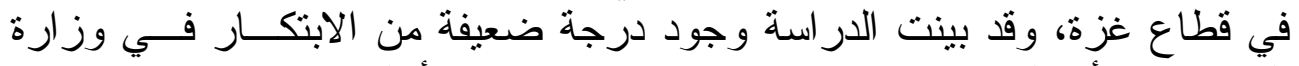

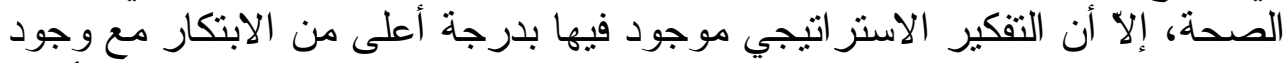

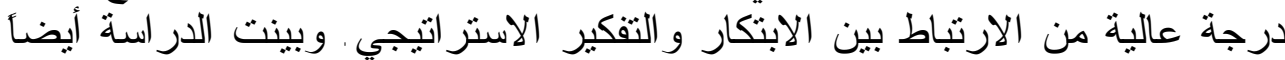

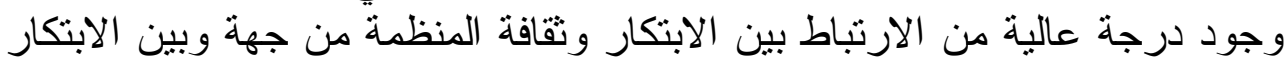

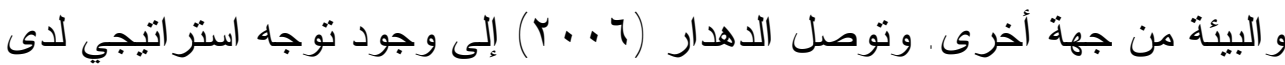

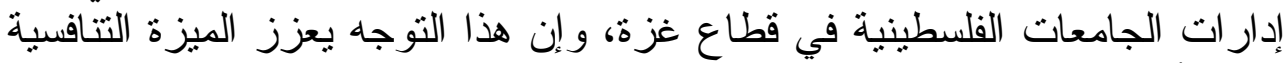

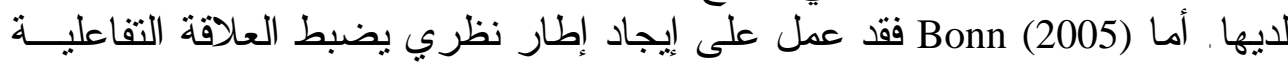

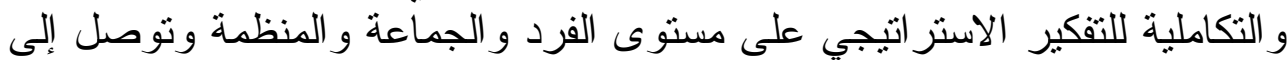
أهمية التكامل في التفكير الاستر اتيجي على كافة المستويات للارتقاء بمستوى التميز ل الهذه المنظمات.

$$
\begin{aligned}
& \text { الحادي عشر - الإطار العملي للاراسة } \\
& \text { يتكون من ثلاثة أقسام وهي: }
\end{aligned}
$$

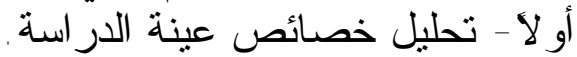

$$
\begin{aligned}
& \text { ثانياً - تحليل ومناقثة أبعاد / محاور الدر اسة. } \\
& \text { ثالثأ - اختبار فرضيل ـ نيات الدراسة. } \\
& \text { أولاً - تحليل خصائص عينة الدراسة }
\end{aligned}
$$

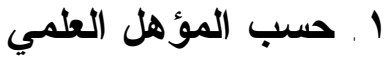

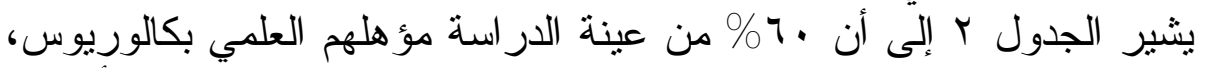

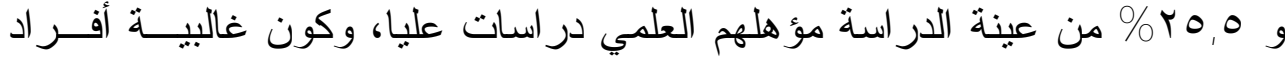


العينة 10,0\% من حملة البكالوريوس فأعلى، فهذا يدل على مستوى على عي عـالٍ

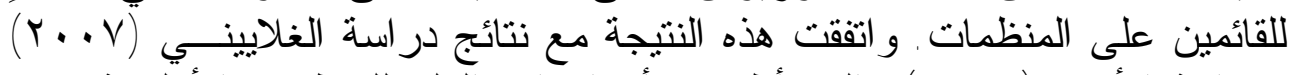

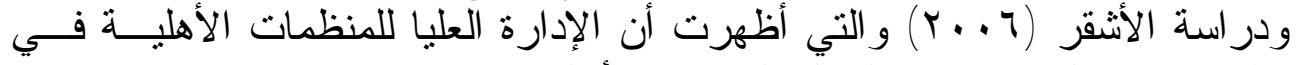

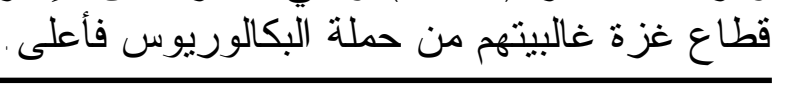

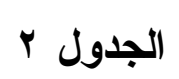

توزيع عينة الار اسة حسب متغير المؤهل العلمي

\begin{tabular}{|c|c|c|}
\hline النسبة المئوية & التكر ار & المؤهل العلمي \\
\hline$r 0,0$ & $r \mu$ & در اسات عليا \\
\hline 7. & $0 \leqslant$ & بكالوريوس \\
\hline 1. & 9 & دبلوم متوسط \\
\hline$\varepsilon, 0$ & $\varepsilon$ & ثانوية عامة فاقل \\
\hline $1 \cdots, \cdot$ & 9. & المجموع \\
\hline
\end{tabular}

\section{r r أنجب سنوات الخبرة}

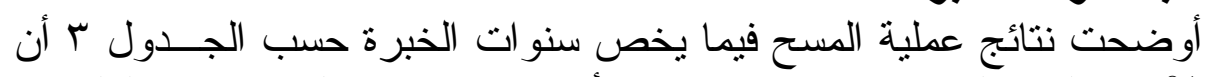

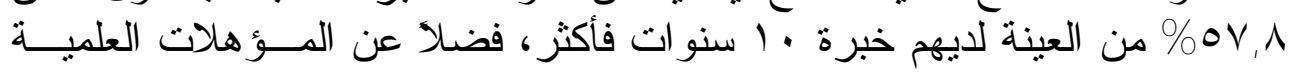

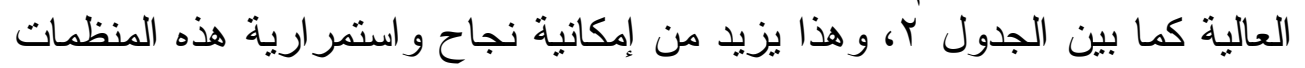

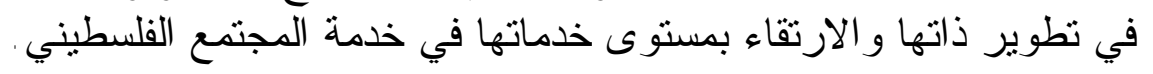

\begin{tabular}{|c|c|c|}
\hline \multicolumn{3}{|c|}{ 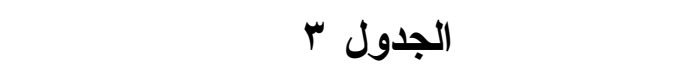 } \\
\hline النسبة المئويةة & التكرار & سنوات الخبرة \\
\hline 0,0 & 0 & أقل من 0 سنو ات \\
\hline$r 7, V$ & $r \mu$ & $1 \ldots 0$ \\
\hline$O V, \Lambda$ & Or & أكثر من · ا سنوات \\
\hline $1 \cdots$, & 9. & المجموع \\
\hline
\end{tabular}

\section{r ب العب العمر الزمني للمنظمة}

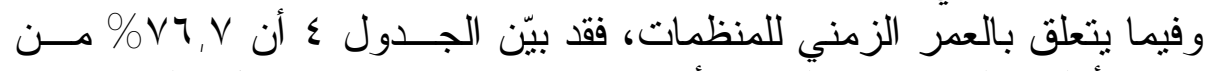

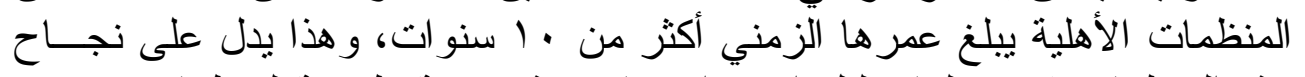

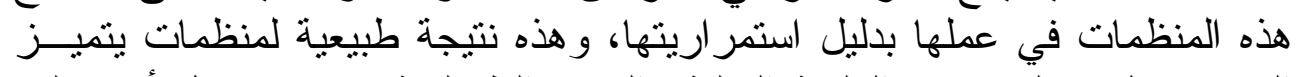

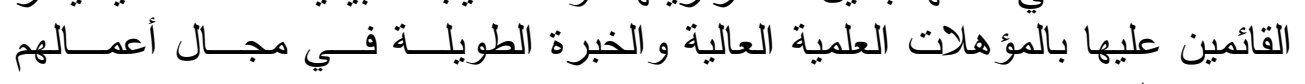




\begin{tabular}{|c|c|c|}
\hline ل للمنظمة بالسنوات & ر الز - الز & نة الدر اسة حسب متغير الإل \\
\hline النسبة المئويةة & التكر ار & العمر الزمني للمنظمة بالسنوات \\
\hline$r, r$ & $r$ & |- 1 سنو ات \\
\hline$r \cdot$ & 11 & 7 \\
\hline$r \varepsilon, 0$ & $\overline{r Y}$ & 10-11 \\
\hline$O r, Y$ & $\leqslant V$ & أكثر من 10 سنة \\
\hline $1 \cdots \cdot$ & 9. & المجموع \\
\hline
\end{tabular}

ع ، حسب عدد العاملين الدائمين بالمنظمة

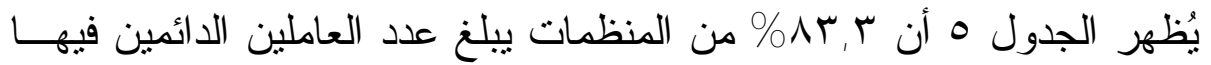

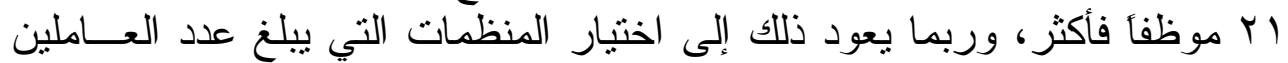

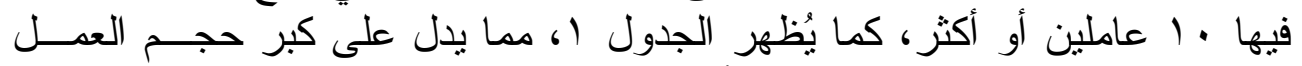

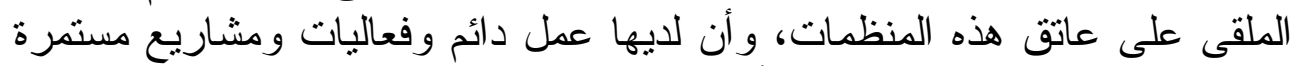

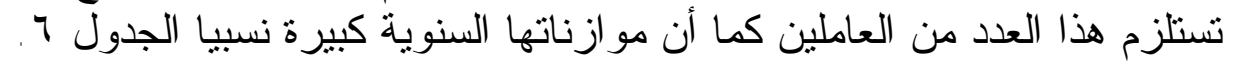

\section{الجدول العال}

توزيع عينة الدراسة حسب عدد العاملين الدائمين بالجمعية

\begin{tabular}{|c|c|c|}
\hline النسبة المئوية & التكر ار & عدد العاملين الدائمين بالجمعية \\
\hline $17, V$ & 10 & 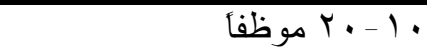 \\
\hline$r q$ & ro & 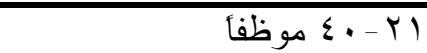 \\
\hline r r & $r$. & 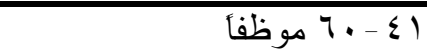 \\
\hline 11 & 1. & آ آ موظفاً فأكثر \\
\hline $1 \cdots$, & 9. & المجموع \\
\hline
\end{tabular}

0. حسب الموازنة السنوية للمنظمة الارئل

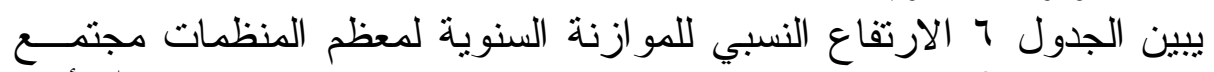

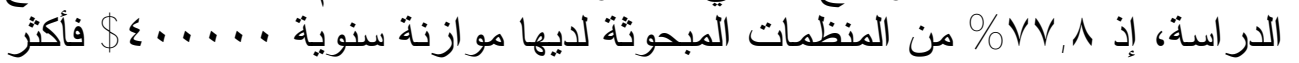

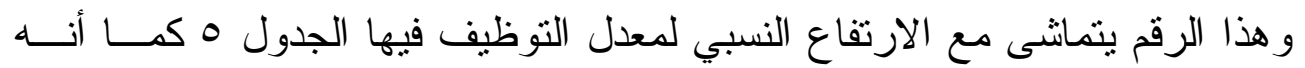

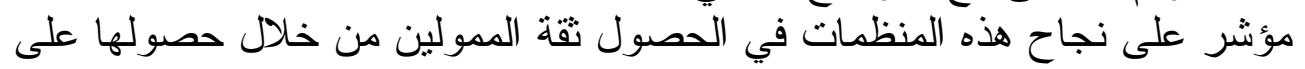

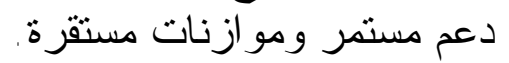




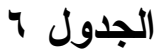

توزيع عينة الدراسة حب متوسط الموازنة السنوية خلا العامين

Y. 7 . Y. . 0

\begin{tabular}{|c|c|c|}
\hline النسبة المئوية & التكر ار & المتوسط السنوي للموازنة \\
\hline 0,0 & 0 & $\$ r \ldots \ldots$ \\
\hline $17, V$ & 10 & $\$ \varepsilon \ldots \ldots$ \\
\hline$\varepsilon \varepsilon, 0$ & $\varepsilon$. & $\$ 7 \ldots \ldots$ \\
\hline r & r. & ....... . \\
\hline $1 \cdots \cdot$ & 9 . & المجموع \\
\hline
\end{tabular}

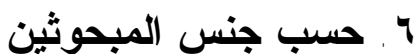

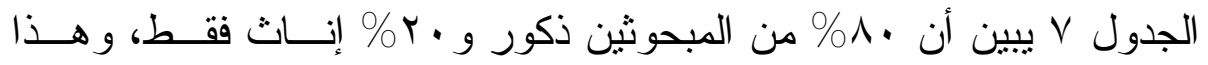

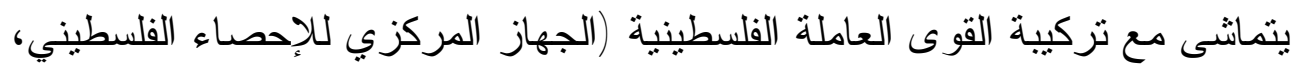

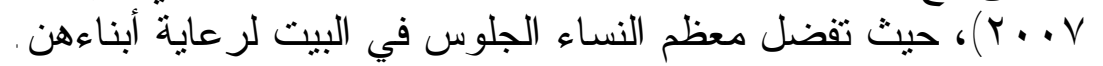

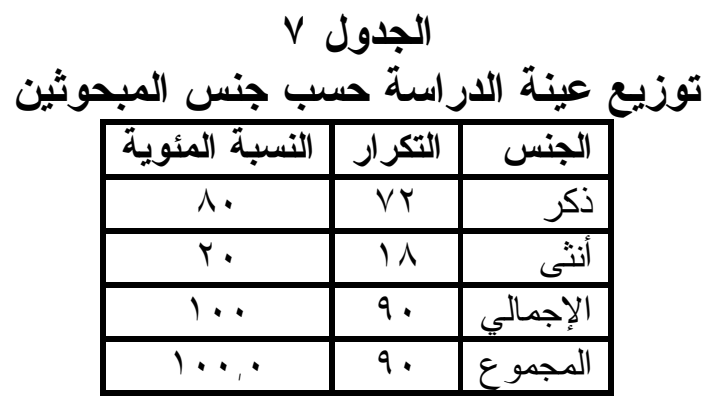

ثانياً - تحليل ومناقثة أبعاد التفكير الاستر اتيجي في المنظمات المبحوثة

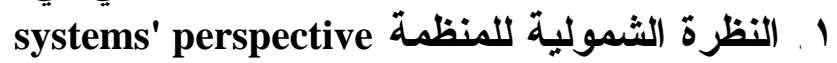

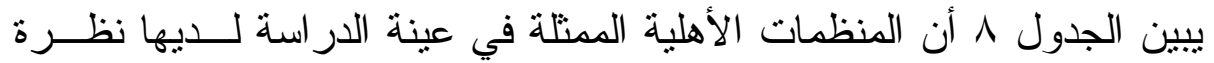

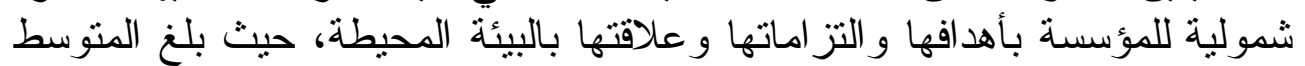

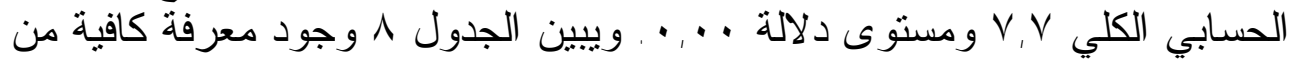

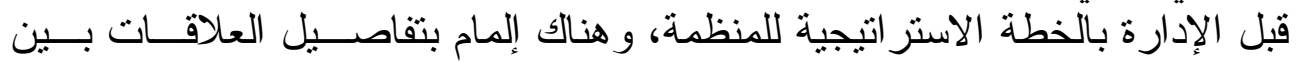

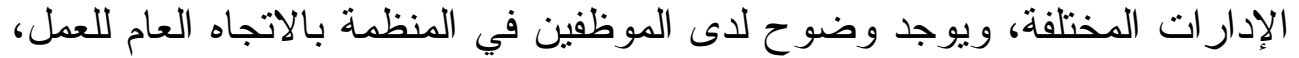

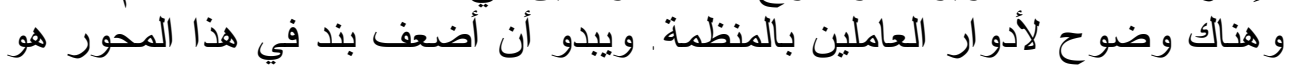

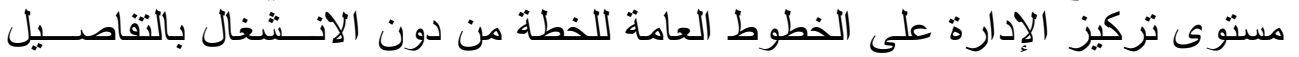


الدكتور الفرا [4؛

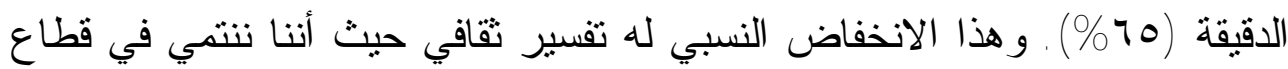

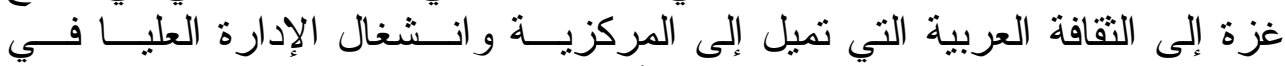
المنظمات بتفاصيل العمل سو اء الروتيني أو غير الروتيني (الفرا، ب . . ب).

\section{الجدول}

مستوى شمولية نظرة قادة المنظمة بالعوامل المؤثرة عليهم لاستخدام

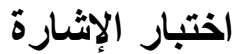

\begin{tabular}{|c|c|c|c|}
\hline الاشنبارة & المئنسبة & الحستوسط & \\
\hline$\cdot, \cdot \cdot$ & المويد & الحستبي & والدور معرفة كافية بالخطة الاستر اتيجية للمؤسسة \\
\hline$\cdot, \cdot \cdot$ & 70 & 7,0 & 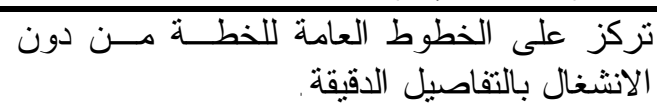 \\
\hline$\cdot, \cdot \cdot$ & ᄉ. & $\Lambda$ & 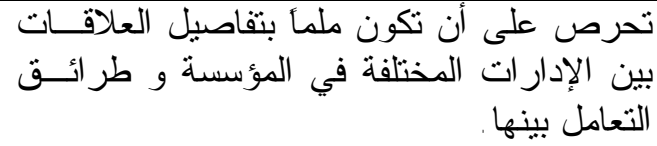 \\
\hline$\cdot, \cdot$ & 10 & 1,0 & 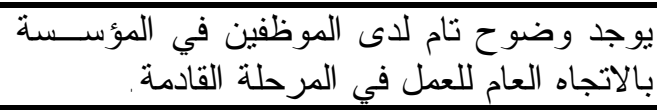 \\
\hline$\cdot, \cdot \cdot$ & Ar & $\Lambda, Y$ & 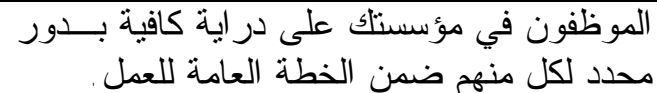 \\
\hline$\cdot, \cdot \cdot$ & A. & $\wedge$ & 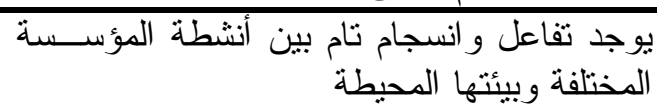 \\
\hline$\cdot, \cdot \cdot$ & $\% \vee v$ & $v, v$ & الإجمالي \\
\hline
\end{tabular}

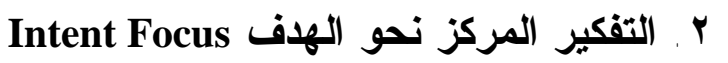

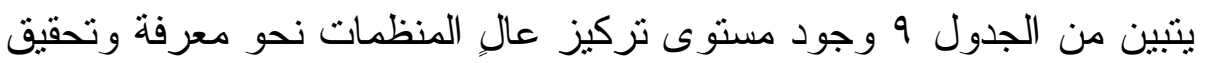

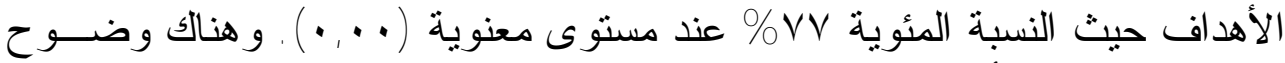

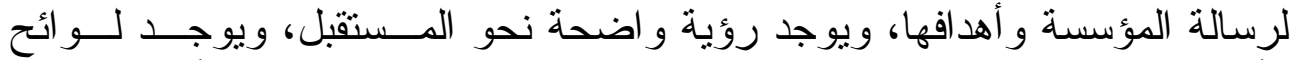

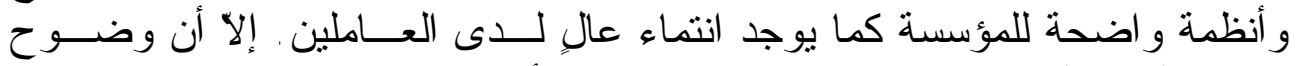

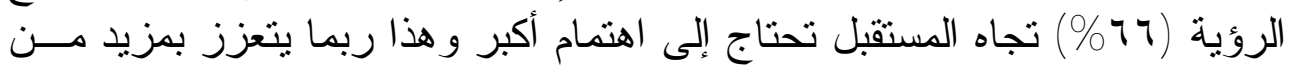

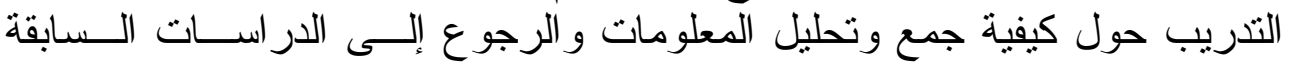

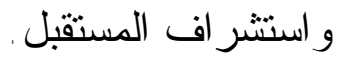




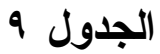

مستوى تركيز تفكير قادة المنظمة نحو الهدف باستخدام اختبار الإثارة

\begin{tabular}{|c|c|c|c|}
\hline 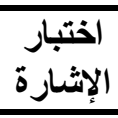 & المئوية & الحسابي & \\
\hline$\therefore, \cdots$ & $\Lambda$. & $\wedge$ & رسالة المؤسسة و أهد افها و اضحة لديك \\
\hline$\cdot, \cdots$ & $V \varepsilon$ & $v, \varepsilon$ & 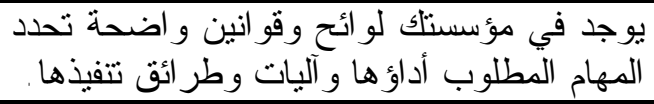 \\
\hline$\because \cdots$ & 77 & 7,7 & 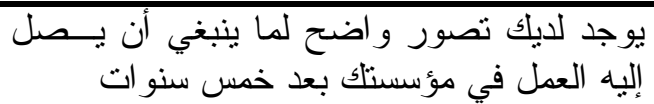 \\
\hline$\therefore, \cdots$ & TV & $7, V$ & 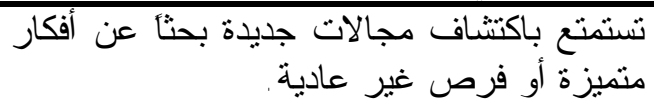 \\
\hline$\because, \cdots$ & 19 & 1,9 & 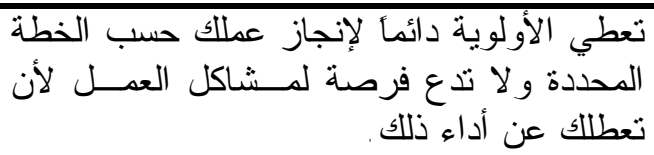 \\
\hline$\cdot \cdots$ & $\wedge 7$ & $\Lambda, 7$ & لديك انتماء وحب عالٍ للمؤسسة. \\
\hline 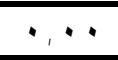 & $\% \vee V$ & $V, v$ & الإجمالي \\
\hline
\end{tabular}

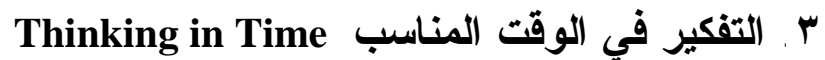
تفكر المنظمات الفلسطينية في غزة في الوقت المناس المناسب في التعامل مع مختلف

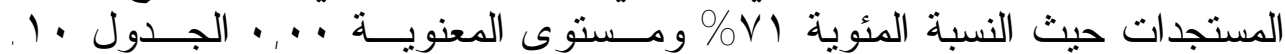

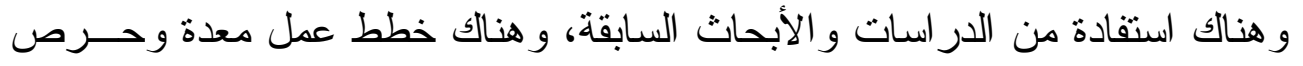

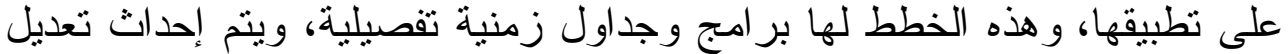

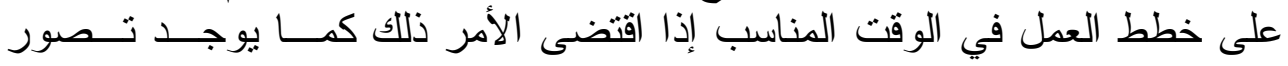
و اضح حول كيفية إحداث تغيير جذري في مستقبل المؤسسة.

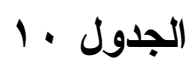

مستوى تفكير قادة المنظمة في الوقت المناسب باستخدام اختبار الإثنارة

\begin{tabular}{|c|c|c|c|}
\hline 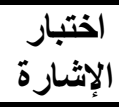 & النسبة المئوية & الحستبي & \\
\hline$\because, \cdot$ & 71 & 7,1 & خطنة العمل. بالدر اسات السابقة و الأبحاث في وضــع \\
\hline$\because, \cdot$ & V. & V & 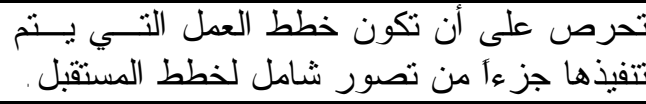 \\
\hline$\because \cdots$ & $V T$ & $v, r$ & 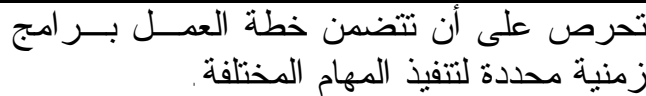 \\
\hline
\end{tabular}




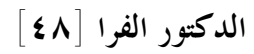

\begin{tabular}{|c|c|c|c|}
\hline الإختبارة & النسبة المئوية & الحسبي & \\
\hline$\cdot, \cdot$ & 71 & 7,1 & 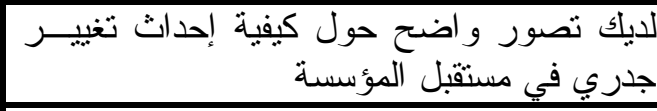 \\
\hline$\because, \cdot$ & $\vee \wedge$ & $v, \Lambda$ & 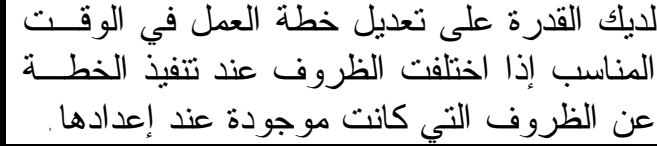 \\
\hline , & $\% \vee 1$ & $v, 1$ & الإجمالي \\
\hline
\end{tabular}

ع ـ تطوير الافتراضات Hypothesis Driven

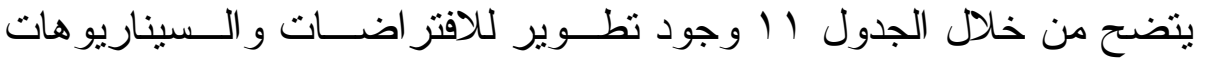

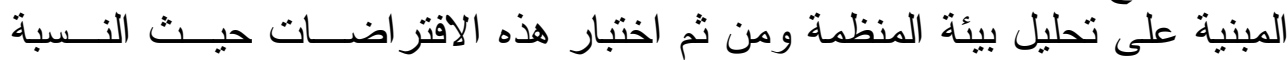

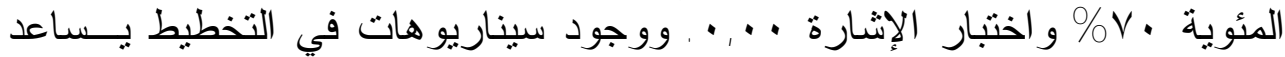

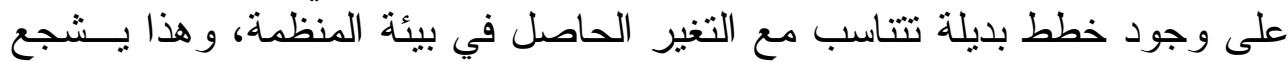

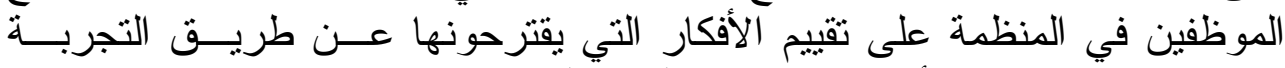

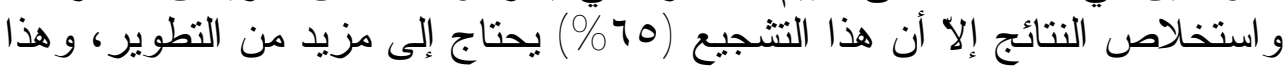

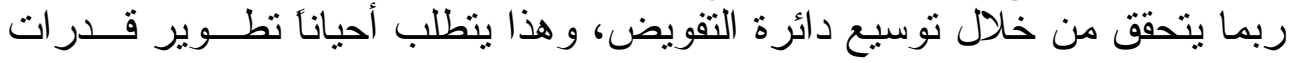
الموظفين كي يكونو ا قادرين على تحمل مسؤوليات ونئ ومهام جديدة.

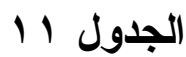

مستوى تطوير قادة المنظمة لافتراضات مبنية على الظروف البيئية المحيطة واختبارها باستخدام اختبار الإثارة

\begin{tabular}{|c|c|c|c|}
\hline 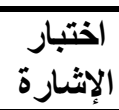 & 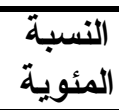 & ال المستوسط & \\
\hline$\cdot, \cdots$ & $\Lambda_{7}$ & 1,7 & العمل الديطيطة. في المؤسسة يعتمد على تحليـلـل بيئــة \\
\hline$\cdot, \cdot \cdot$ & 77 & 7,7 & 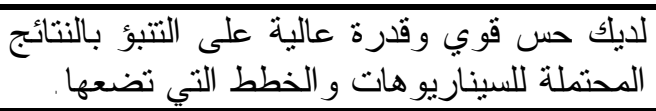 \\
\hline$\cdot, \cdot$ & 71 & $7, \wedge$ & 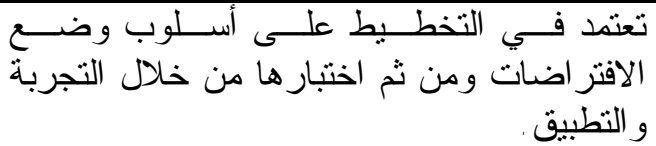 \\
\hline$\because, \cdots$ & TV & 7,5 & 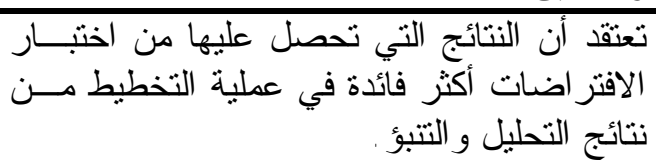 \\
\hline$\cdot, \cdots$ & 70 & 7,0 & 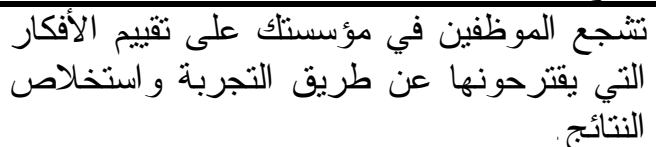 \\
\hline
\end{tabular}




\begin{tabular}{|c|c|c|c|}
\hline 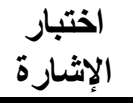 & المئوية النسبة & المستوسي & \\
\hline$\cdot, \cdots$ & 71 & $7, \wedge$ & 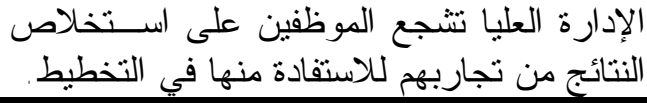 \\
\hline$\cdots$ & $\% \vee$. & $\mathrm{V}$ & الإجمالي \\
\hline
\end{tabular}

هـ الفرصة الذكية Intelligent Opportunity

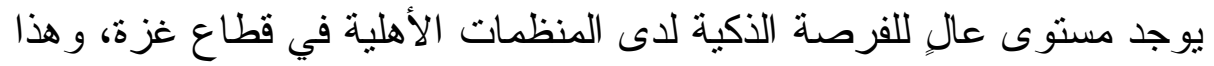

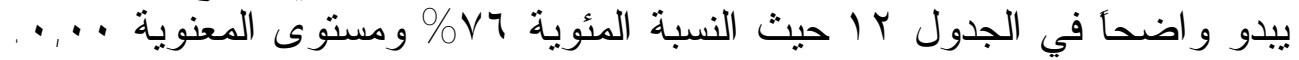

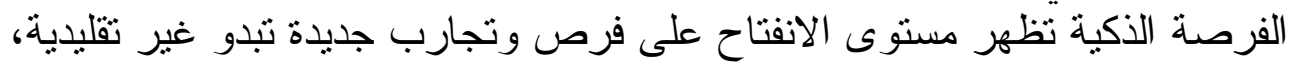

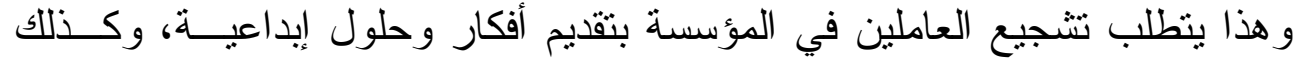

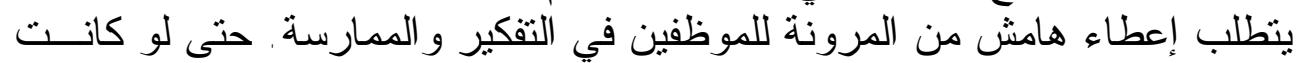

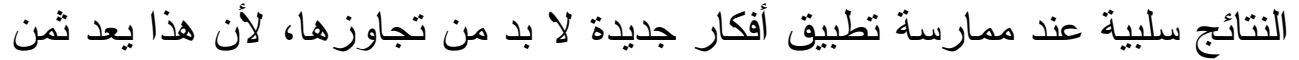

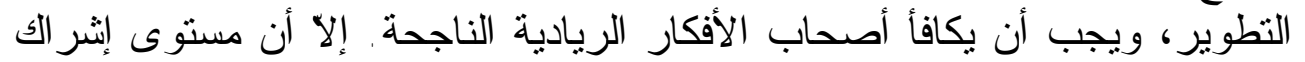

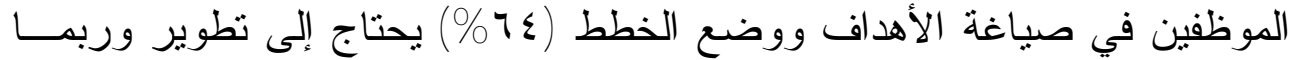

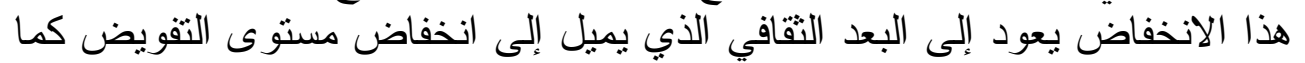

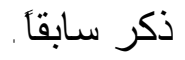

\begin{tabular}{|c|c|c|c|}
\hline \multicolumn{4}{|c|}{ 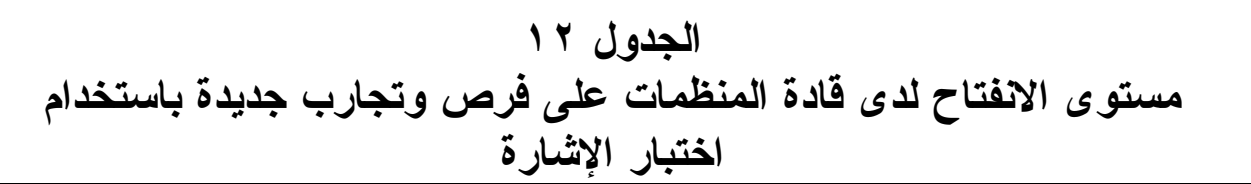 } \\
\hline الإشتبارة & المئويبة & الحستوسطي & \\
\hline$\because \cdots$ & $T \varepsilon$ & $7, \varepsilon$ & 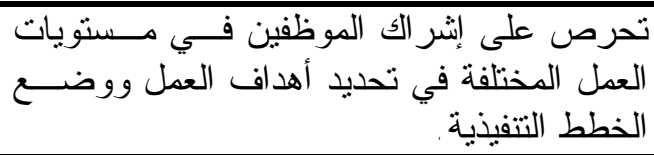 \\
\hline$\because \cdots$ & $\vee \cdot$ & $\checkmark$ & تسعى للحصر متعددة. على أفكار جديدة لتطوير العمل \\
\hline$\because \cdots$ & $\vee 9$ & $\vee, q$ & تغير الظروف الاستعداد لتعديل استر اتيجية العمل في حال \\
\hline$\because \cdots$ & $\wedge \wedge$ & $\wedge, \wedge$ & 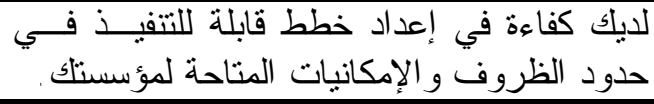 \\
\hline$\because \cdots$ & $\wedge$. & $\wedge$ & تلغير الظروف خطط المحيطة امجيلة يمكن اللجوء إليها عند \\
\hline$\cdot, \cdots$ & $\% \vee 4$ & $V, 7$ & الإجمالي \\
\hline
\end{tabular}




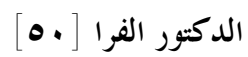

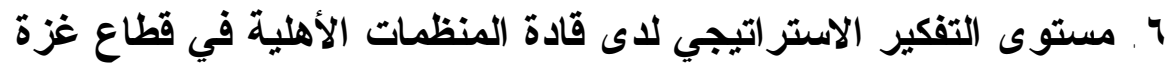

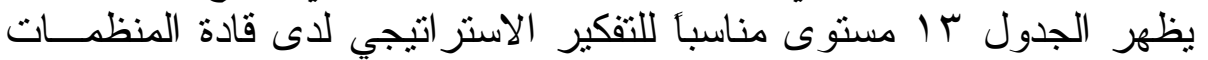

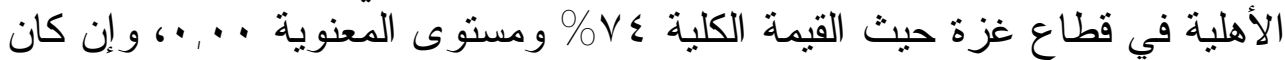

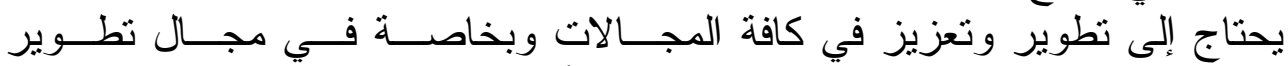

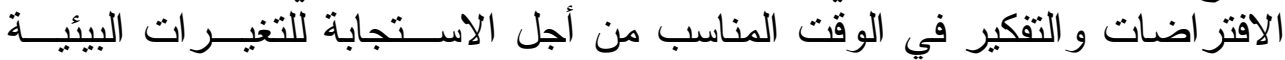

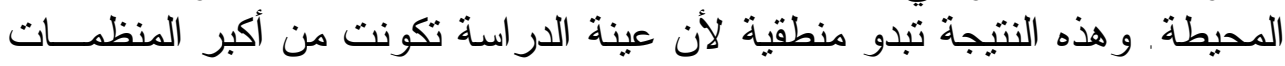

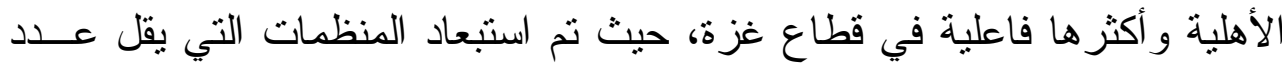

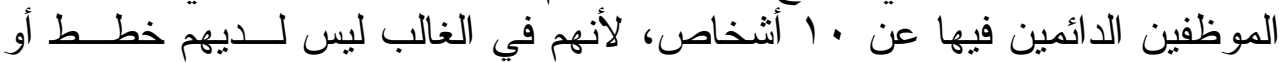

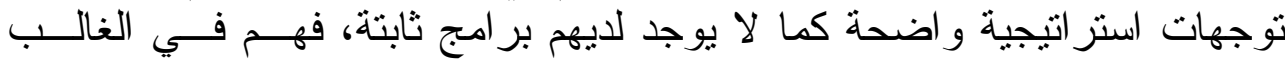

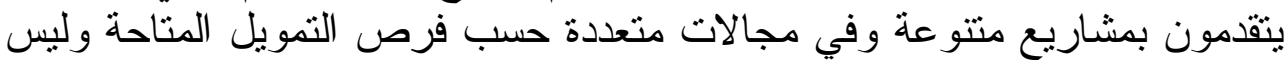

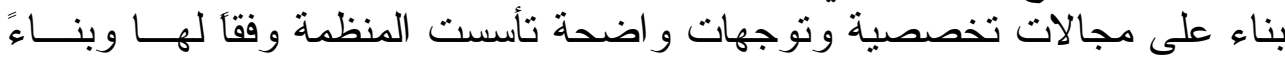

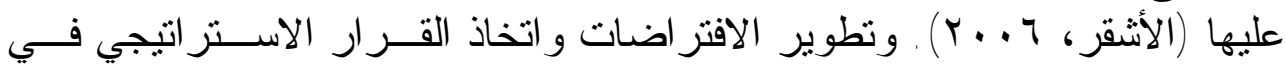

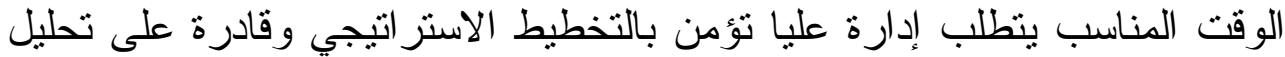

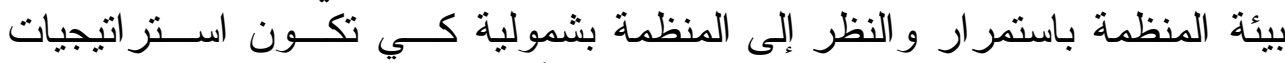

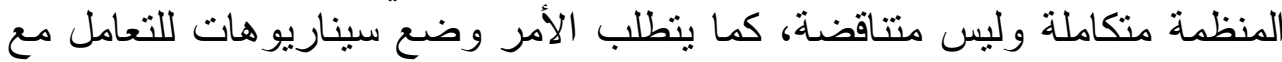

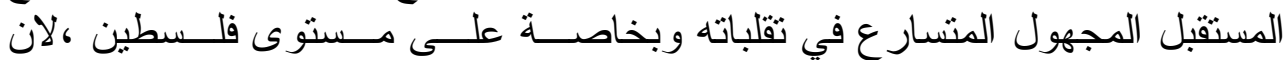

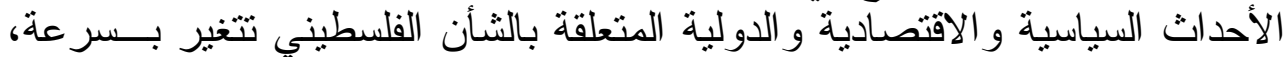

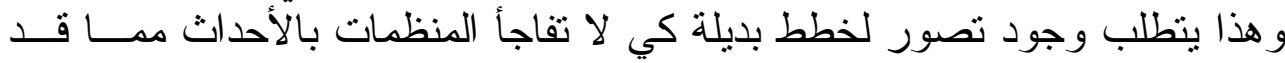

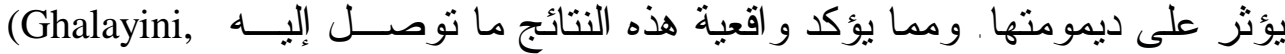

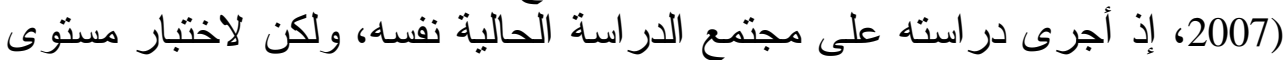

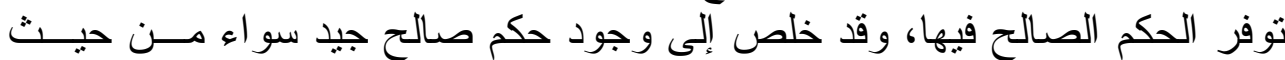

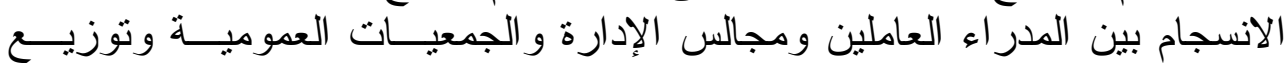

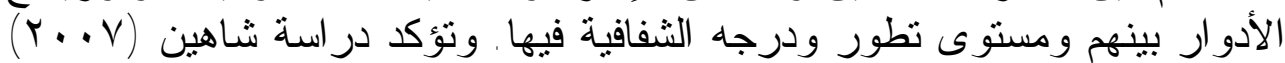

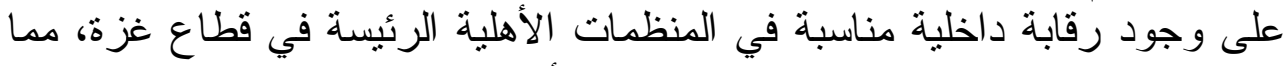

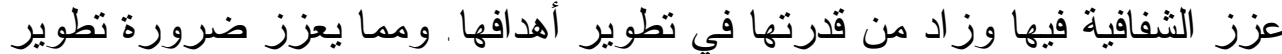

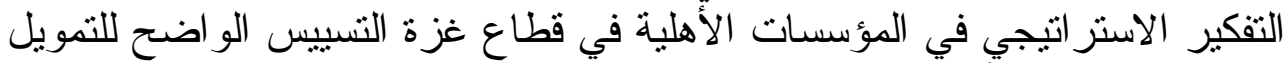

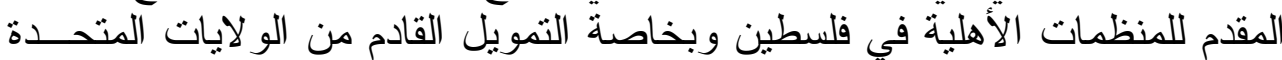

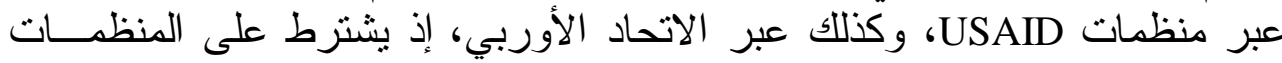

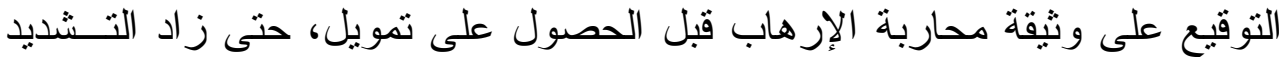

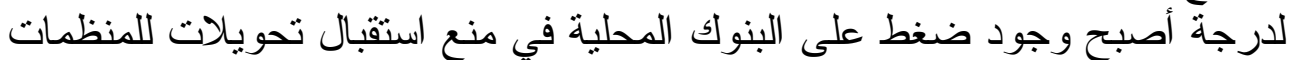

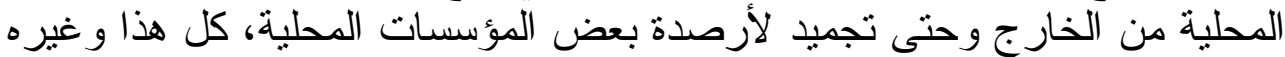

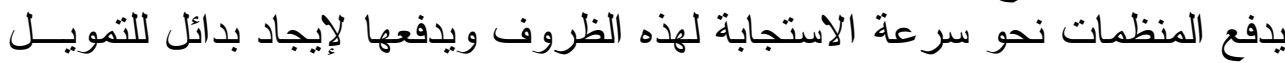
منل تطوير التمويل الذاتي وغيره.

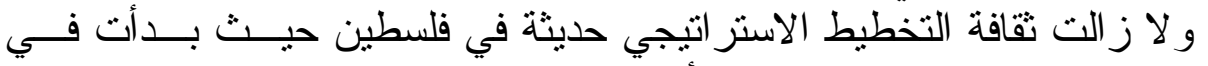

أو اخر التسعينات وبخاصة بعد اتفاقية أوسلو وقدوم السلطة الفلسطينية إلى القطــــاع 


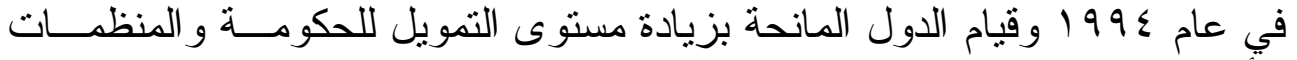

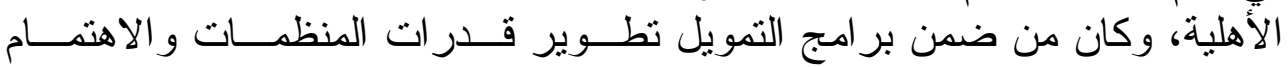

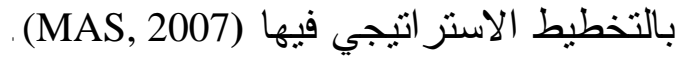

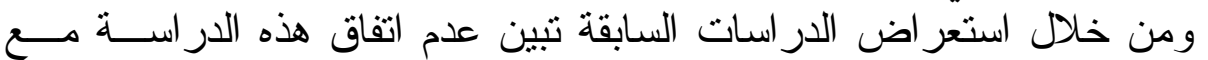

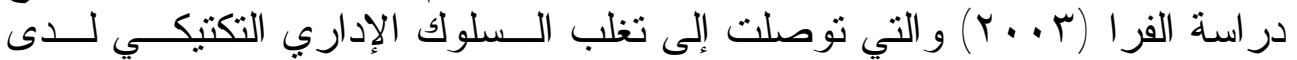

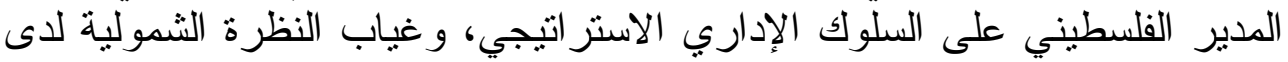

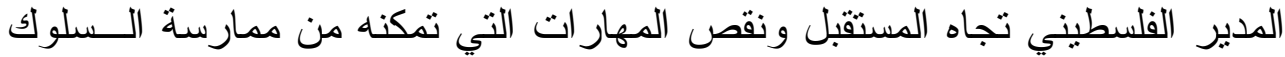

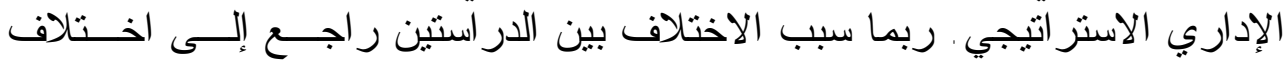

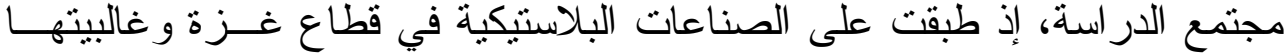

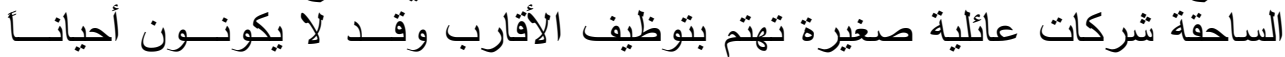

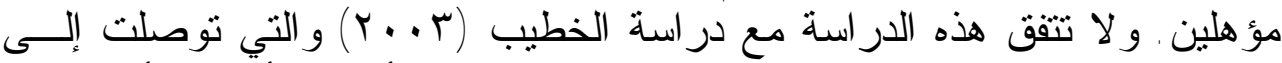

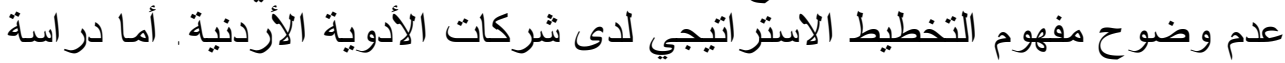

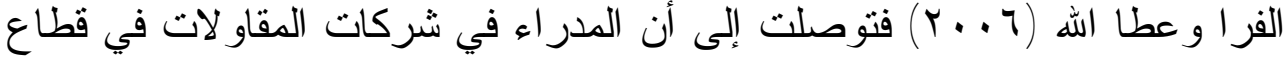

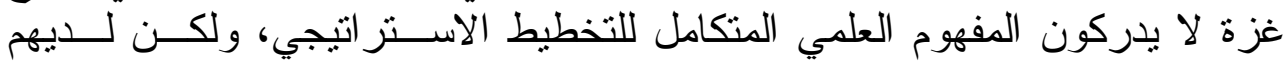

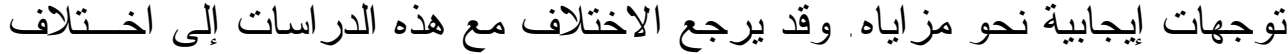

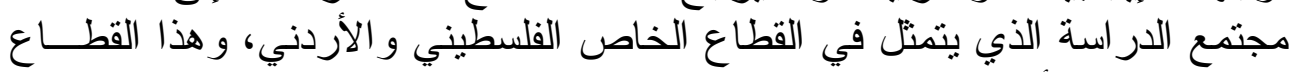

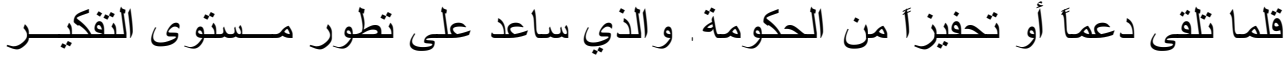

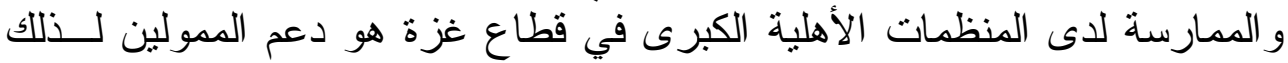

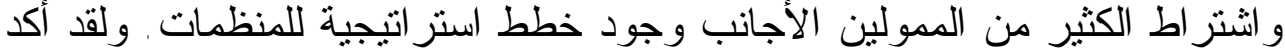

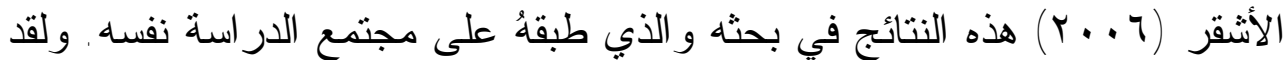

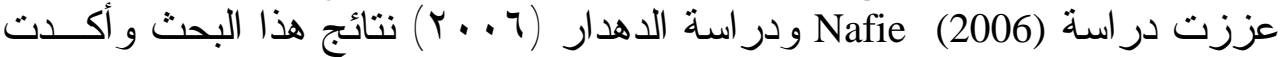

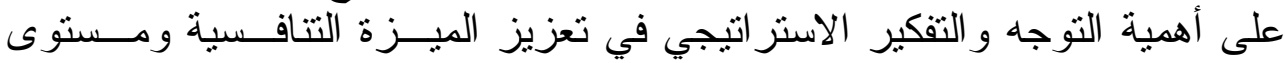

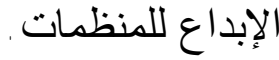

\begin{tabular}{|c|c|c|c|}
\hline غزة باستخدام & أهلية في قطا. & الجدول إدبار المنظمات & مستوى التفكير الاستر \\
\hline اختبار الإشارة & النسبة المئوية & المتوسط الحسابي & \\
\hline$\cdot \cdots$ & $V V$ & $V, V$ & النظرة الثمولية للمؤسسة \\
\hline$\because \cdots$ & $V V$ & $V, V$ & التفكير المركز نحو الهذف \\
\hline$\cdot, \cdots$ & VI & $V, 1$ & التفكير في الوقت المناسب \\
\hline$\because \cdots$ & $V \cdot$ & $\mathrm{V}$ & تطوير الافتر اضات \\
\hline$\because, \cdots$ & $V 7$ & $V, 7$ & الفرصة الذكية \\
\hline$\because \cdots$ & $\% \vee \varepsilon$ & $V, \varepsilon$ & الإجمالي \\
\hline
\end{tabular}


الدكتور الفرا [0r]

ثالثا - اختبار فرضية الاراسة

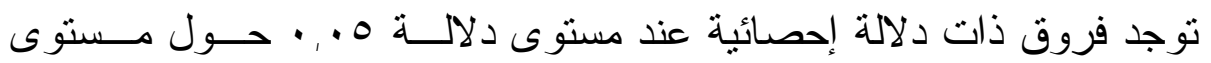

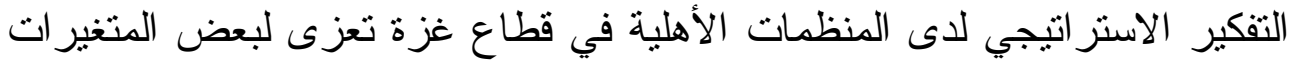

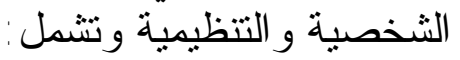

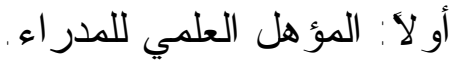

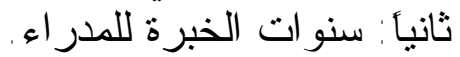

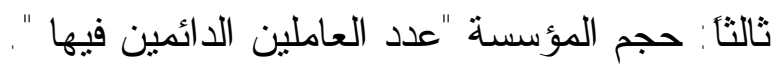
رابعأ: العمر الزمني المؤمة المؤسسة. خامساً: الموازنة السنوية سادسأ: جنس أمبح المبحثين لقد تم اختبار الفرضية عبر الجداول ع ا إلى 9 ألى وحسب التحليل الآتي:

أولاً - المؤهل العلمي للمدراء

\section{الجدول ع أ}

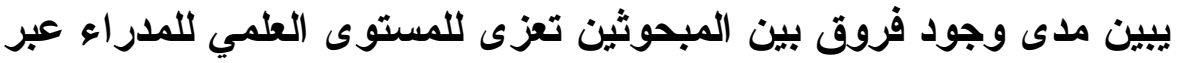
استخدام اختبار كروسكال وليس ليسن

\begin{tabular}{|c|c|c|c|c|c|c|}
\hline \multirow[b]{2}{*}{ الدلالة } & \multirow[b]{2}{*}{ مربع كاي } & \multicolumn{4}{|c|}{ المتوسط الحسابي } & \multirow[b]{2}{*}{ الفقرة } \\
\hline & & در عليات & جامعي & دبلوم & ثانوية فأقلّ & \\
\hline$\cdot, \varepsilon \varepsilon$. & $r, Y$. & $\mathrm{v}, \mathrm{\Lambda}$ & $V, \Lambda$ & $V, V$ & $V, 7$ & النظرة الثمولية للمؤسسة \\
\hline$\cdot, Y \mu$. & $\varepsilon, \cdot r$. & $V, V O$ & $V, V$ & $V, T \leq$ & $V, 77$ & التفكير المركز نحو الهذف \\
\hline$\cdot, r \leqslant Y$ & $\varepsilon, \wedge \wedge$ & $V, Y$ & $v, 1$ & V & $\mathrm{V}$ & التفكير في الوقت المناسب \\
\hline$\cdot, V \vee$. & $\cdot, r \vee T$ & $\frac{V, 1}{2}$ & $V$ & 7,9 & $7, \mathrm{AV}$ & تطوير الافتز اضات \\
\hline$\cdot, \wedge \vee q$ & $\cdot 97 \mathrm{~V}$ & $V, T$ & $V, 7$ & $V, 00$ & $V, 0 \leqslant$ & الفرصة الذكية \\
\hline., $07 \varepsilon$ & 1,507 & $V_{1} \leqslant \Lambda$ & $V, \varepsilon \leqslant$ & $V, r q$ & $V, r Y$ & الإجمالي \\
\hline
\end{tabular}

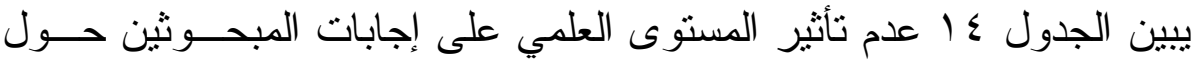

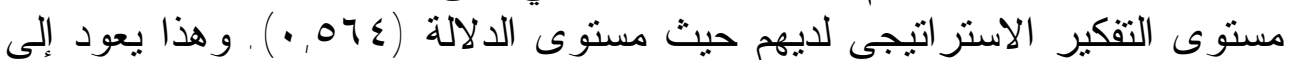
أن ^0,0\% من المبحوثين الجدول r حاصلون على درجة بكالوريوس أو أعلى.

\section{ثانياً - سنوات الخبرة للمدراء}

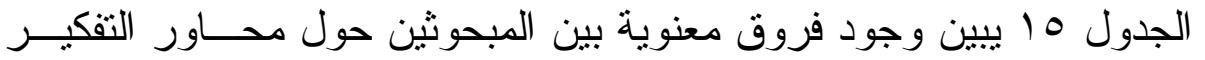

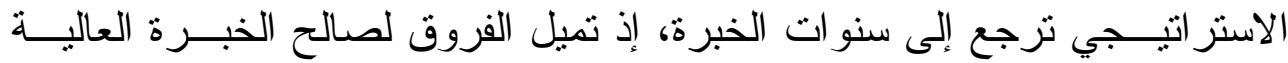

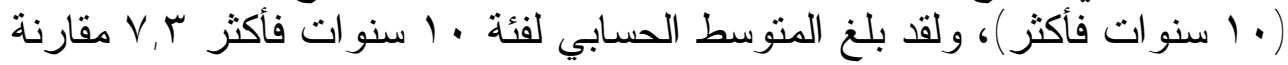




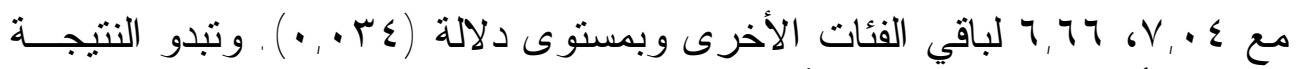

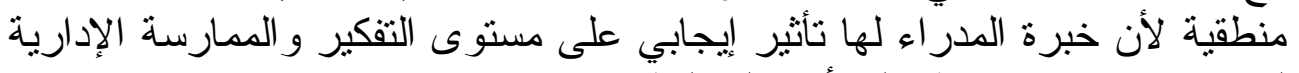
لديهم مما ينعكس إيجاباً على أداء المنظمة. لألير.

\section{الجدول 10}

مدى وجود فروق بين المبحوثين تعزى لسنوات الخبرة للمدراء عبر استخدام اختبار كروسكال وليس تونيس

\begin{tabular}{|c|c|c|c|c|c|}
\hline \multirow{2}{*}{ الدلالة } & \multirow[b]{2}{*}{ مريع كاي } & \multicolumn{4}{|c|}{ المتوسط الحسابي } \\
\hline & & ـ ا فأكثر & $1 \ldots 0$ & أقلّ من & الفقرة \\
\hline$\cdot, \cdot \leq \Gamma$ & $r 0, r Y$ & $v, q$ & $V, Y$ & 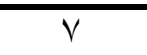 & النظرة الثمولية للمؤسسة \\
\hline$\frac{., \cdot T r}{T Y}$ & $\varepsilon 0, Y \mu$ & $\overline{V, \Lambda}$ & $V, \varepsilon$ & 7,1 & التنفكير المركز نحو الهدف \\
\hline$\cdot, \cdot r$ & $r \leqslant, 90$ & $V, \varepsilon$ & $\mathrm{v}$ & $7, \varepsilon$ & التنكير في الوقت المناسب \\
\hline$\cdot, \cdot, r)$ & $r \varepsilon, r)$ & $V, r$ & $7, \xi$ & 7,1 & تطوير الافتراضات \\
\hline$\cdot \cdot, Y$ & $0 \xi, r \xi$ & $v, \Lambda$ & $V, r$ & $\mathrm{v}$ & الفرصة الذكية \\
\hline$\therefore$ & $\varepsilon \cdot, \leqslant 0$ & $V, T \varepsilon$ & $v_{,} \cdot \varepsilon$ & 7,74 & الإجمالي \\
\hline
\end{tabular}

ثالثاً - حجم المؤسسة "عدد العاملين الدائمين فيها"

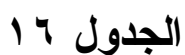

مدى وجود فروق بين المبحوثين تعزى لعدد العاملين في المؤسسة عبر استخدام

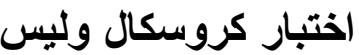

\begin{tabular}{|c|c|c|c|c|c|c|}
\hline \multirow{2}{*}{ مستوى الدلاية } & \multirow{2}{*}{ مربع كاي } & \multicolumn{4}{|c|}{ المتوسط الحسابي } & \multirow{2}{*}{ الفقرة } \\
\hline & & ا آ فأكثر & $7 .-\leq 1$ & $\{\ldots\}$ & $r \cdot-1$. & \\
\hline$\cdot, \cdot r$ & $\mu_{0},$. & $\wedge$ & $V, Y$ & $7, r$ & 7 & النظرة الثمولية للمؤسسة \\
\hline$\cdot \cdots$ & $\varepsilon r, 1$. & $v, q$ & $v, \Lambda$ & $7, \varepsilon$ & $7, r$ & التنفكير المركز نحو الهدف \\
\hline$\because \cdots r$ & $r \cdot, V \cdot$ & $V, q$ & $V, V$ & $7, r$ & $7, \cdot$ & التقكير في الوقت المناسب \\
\hline$\cdot, r \Lambda$ & rᄉ, 11 & 1,1 & $\vee, \wedge$ & $7, \varepsilon$ & $7, r$ & تطوير الافتر اضات \\
\hline$\cdot, \cdot r$ & $0 \cdot, T_{1}$ & $\Lambda$ & $\Lambda$ & 7,1 & $7, \cdot$ & الفرصة الذكية \\
\hline$\cdot, \cdot 1 r$ & $r q, \varepsilon$. & $\vee, V \wedge$ & $\mathrm{V}, \mathrm{V}$ & $7, Y \wedge$ & $7,1 Y$ & الإجمالي \\
\hline
\end{tabular}

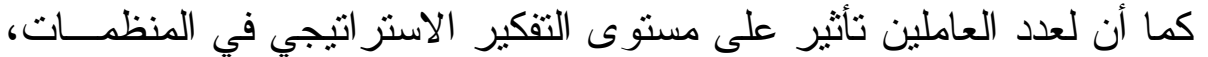

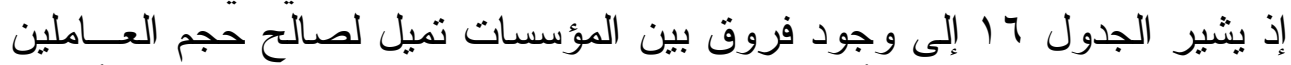

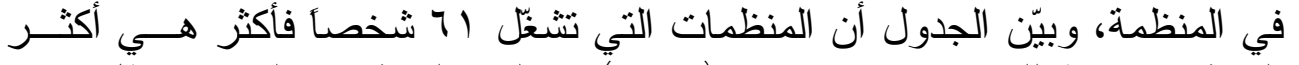

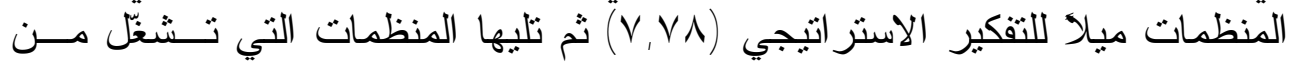


الدكتور الفرا [ـ0]

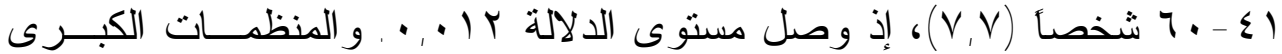

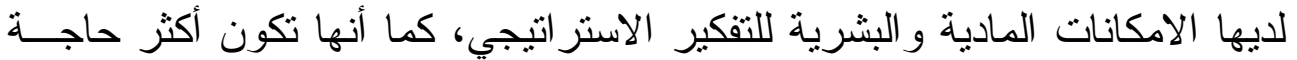
للتفكير الإستر اتيجي بسبب ضخامة وتعقيد العمل. وكبر حجم العاملين لديهم دليـلـل

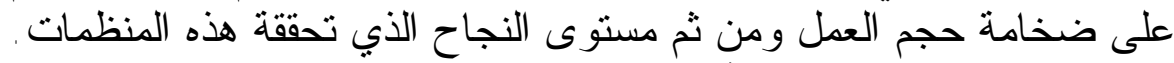
رابعاً - العمر الزمني للمنظمة همن

\begin{tabular}{|c|c|c|c|c|c|c|}
\hline \multirow[b]{3}{*}{ مستوى الدلاكة } & \multicolumn{6}{|c|}{ مدى وجود فروق بين المبحوثين تعزى للعمر الزمني للمؤسسة عبر استخد } \\
\hline & \multirow[b]{2}{*}{ مربع كاي } & \multicolumn{4}{|c|}{ المتوسط الحسابي } & \multirow[b]{2}{*}{ الفقرة } \\
\hline & & أكثر من & $10-11$ & $1 \cdot-7$ & | 1 -0 سنوات & \\
\hline$\cdot \cdot \cdot r$ & ro,rr & $V, q$ & $V, r$ & $\mathrm{~V}$ & $7, r$ & النظرة الثمولية للمؤسسة \\
\hline$\cdot, \cdot 1$ & $\sum 0, Y T$ & $V, 7$ & $V, \varepsilon$ & $7, \varepsilon$ & $7, r$ & التفكير المركز نحو الهوف \\
\hline$\cdot, \cdot r$ & $r \varepsilon, 90$ & $V, 0$ & $\overline{V, r}$ & $7, r$ & 7,1 & التفكير في الوقت المناسب \\
\hline$\cdot, \cdot \leqslant r$ & $r \varepsilon, Y)$ & $V, \varepsilon$ & 7,9 & $7, r$ & $7, Y$ & تطوير الافتز اضات \\
\hline$\cdot \cdot r$ & $0 \leqslant, \Gamma \leqslant$ & $\mathrm{V}, \Lambda$ & $V, 1$ & 7,0 & $7, r$ & الفرصة الذكية \\
\hline$\because, 10$ & $\varepsilon \cdot, \leqslant 0$ & $V, T \leqslant$ & $v, 17$ & $7, \leqslant 1$ & $Y, Y \leq$ & الإجمالي \\
\hline
\end{tabular}

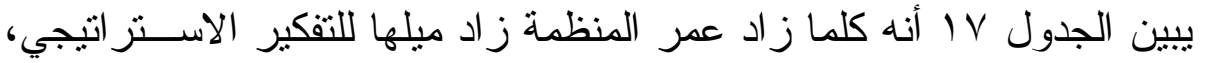

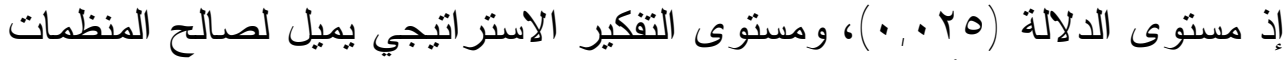

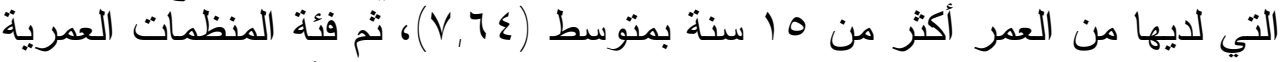

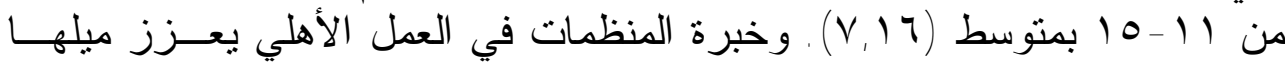

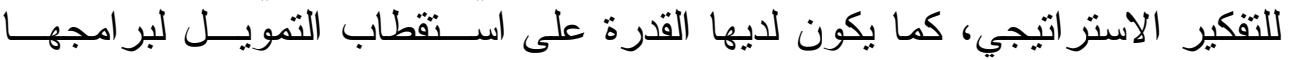

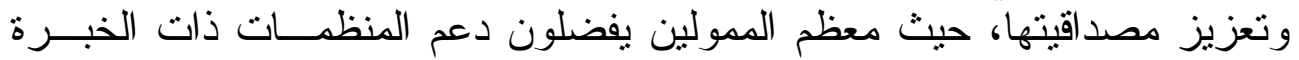
و التي تعمل لفتر ات زمنية طويلة.

خامساً - الموازنة السنوية للمنظمة

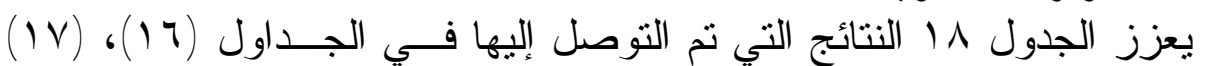

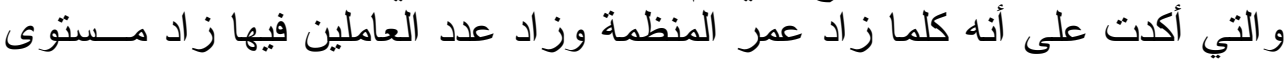

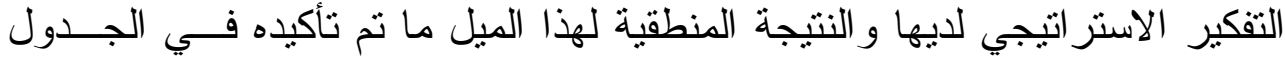

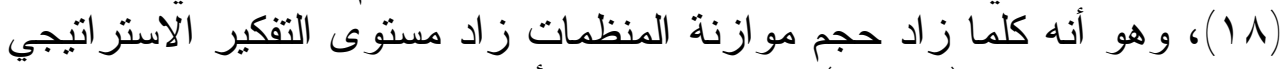

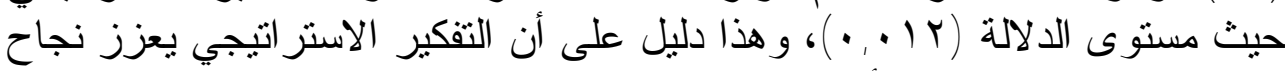

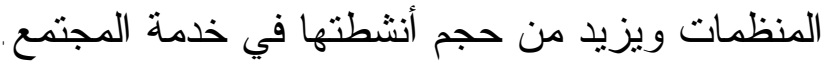




\section{الجدول 1 ا}

يبين مدى وجود فروق بين المبحوثين تعزى لحجم الموازنة السنوية للمنظمة

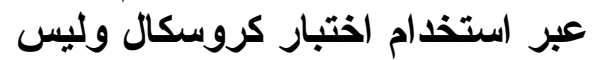

\begin{tabular}{|c|c|c|c|c|c|c|}
\hline \multirow{2}{*}{ الالالة } & \multirow[b]{2}{*}{ مربع كاي } & \multicolumn{4}{|c|}{ المتوسط الحسابي } & \multirow[b]{2}{*}{ الفقرة } \\
\hline & & فأكثر $\$$ & $\begin{array}{c}-\varepsilon \ldots \\
\$ 7 \ldots . .\end{array}$ & $\begin{array}{c}-r \ldots \\
\$ \leqslant \ldots\end{array}$ & $\begin{array}{c}-1 \ldots \\
\$ r \ldots .\end{array}$ & \\
\hline$\cdot, r$ & $r \wedge$, & $\overline{\Lambda, 1}$ & $\mathrm{~V}, \wedge$ & 7,7 & $7, \varepsilon$ & النظرة الثمولية للمؤسسة \\
\hline$\because \cdots$ & $\leqslant 0,1$. & $V, q$ & $V, \varepsilon$ & $7, \varepsilon$ & $7, Y$ & التفكير المركز نحو الهدف \\
\hline$\because \cdots r$ & $r \cdot, 0$ & $\Lambda, r$ & $\mathrm{~V}, \Lambda$ & 7,0 & 7,1 & التفكير في الوقت المناسب \\
\hline$\cdot, \cdot \mu \lambda$ & 00,11 & $\overline{\Lambda, 1}$ & $\mathrm{~V}, \wedge$ & $7, \varepsilon$ & $7, r$ & تطوير الافنز اضات \\
\hline$\cdot, \cdot r$ & $0 ., Y T$ & $\Lambda$ & $V, 0$ & $7, \varepsilon$ & $7, Y$ & الفرصة الذكية \\
\hline$\because, 1 r$ & $\varepsilon \eta, Y$. & $\overline{\Lambda, \cdot 7}$ & 8,79 & 7,87 & $\overline{Y, Y \leq}$ & الإجمالي \\
\hline
\end{tabular}

\section{الجدول 9}

سادساً - جنس المبحوثين

يظهر اختبار مان ويتني Uلقياس دلاحة الفروق بين متوسطات استجابات عينة

\begin{tabular}{|c|c|c|c|}
\hline \multirow{2}{*}{ مستوى الدلاية } & \multicolumn{2}{|c|}{ المتوسط الحسابي } & \multirow{2}{*}{ الفقرة } \\
\hline & إناث & ذكور & \\
\hline$\cdot 1 \ldots$ & $V, 70$ & $V, V O$ & النظرة الثمولية للمؤسسة \\
\hline $.1 \%$ & $V, V$ & $V, V$ & التفكير المركز نحو الهدف \\
\hline$\cdot, Y \mu$. & $\left.v_{1}\right)$ & $V, Y_{0}$ & التفكير في الوقت المناسب \\
\hline$\because \leqslant 0$. & $\mathrm{V}$ & $\mathrm{V}$ & تطوير الافتز اضات \\
\hline • & $V, T V$ & $V, V$ & الفرصة الذكية \\
\hline$\cdot, M Y I$ & $\vee, r \wedge$ & $v, \leqslant 0$ & الإجمالي \\
\hline
\end{tabular}

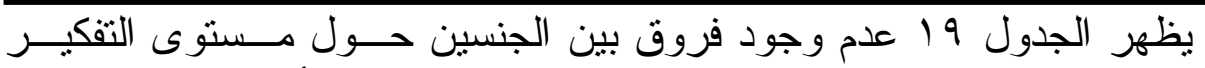

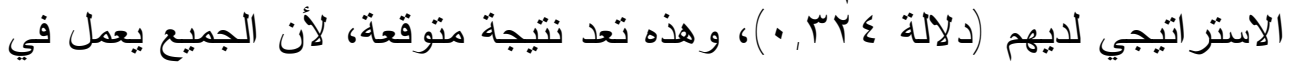

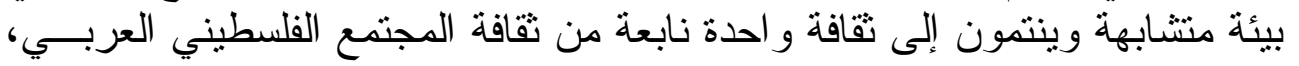

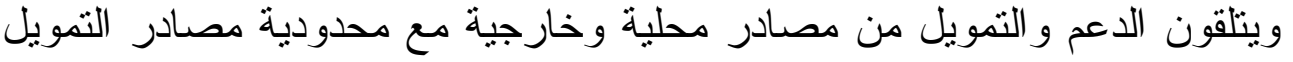




\section{اولا - الفتايج \\ من أبرز}

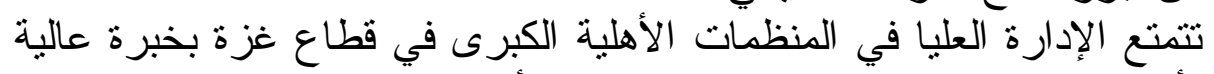

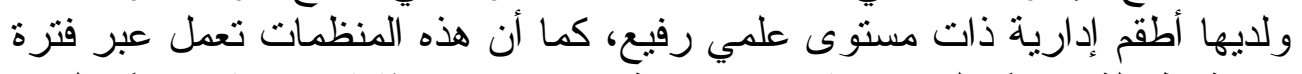

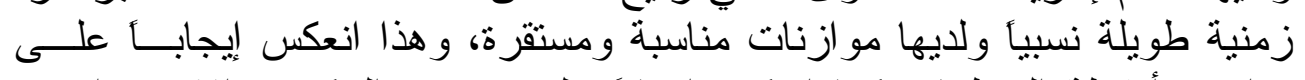

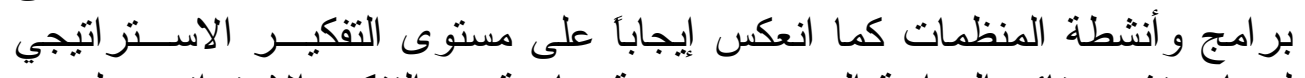

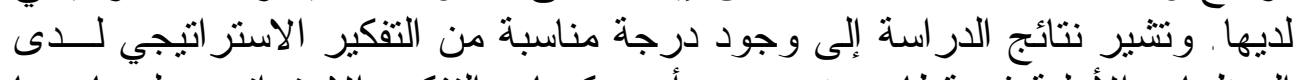

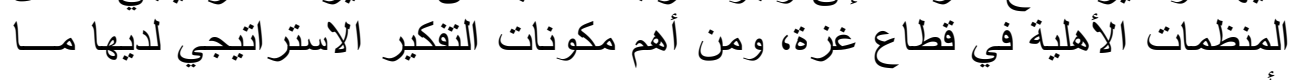
يأتي :

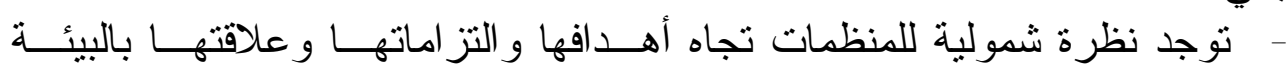
المحيطة، وهناك معرفة كافية لدى الإدارة بالخطة الاستر اتيجية للمنظمة الماته، و إلمام

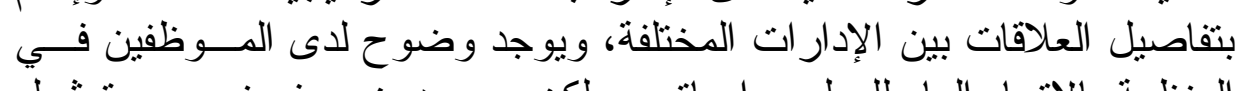

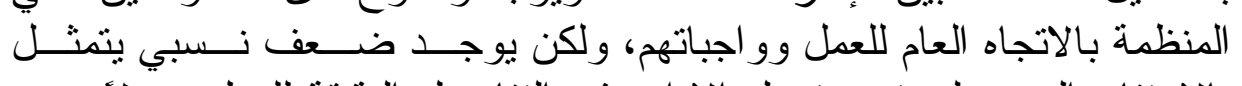

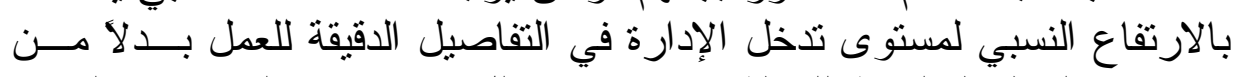

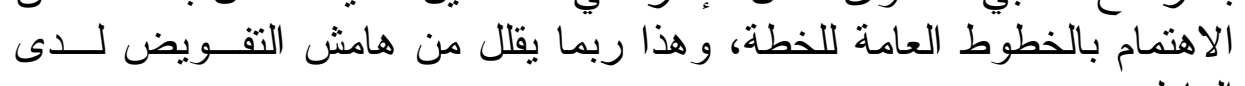

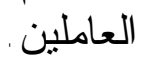

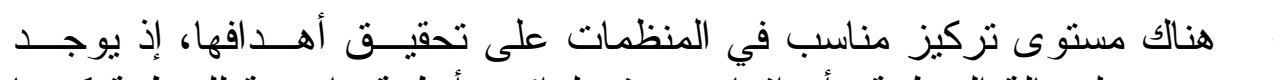

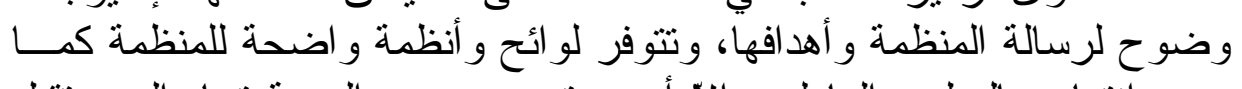

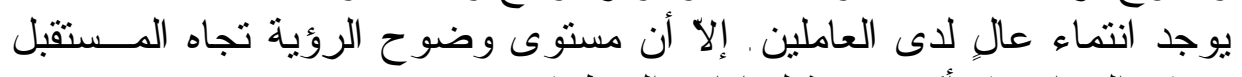

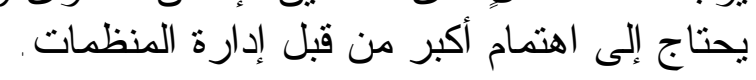

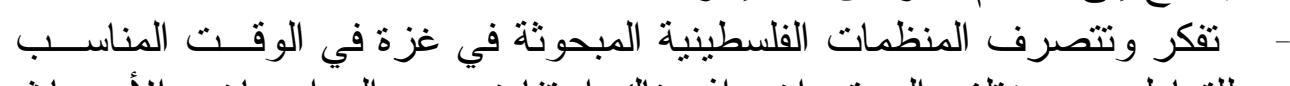

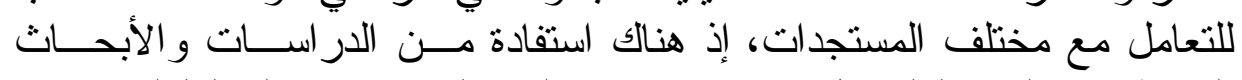

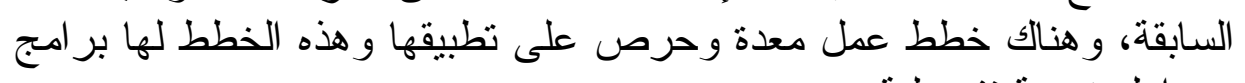
وجداول زمنية تفصيلية.

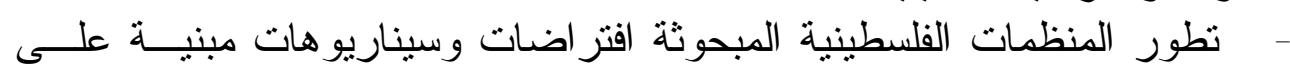

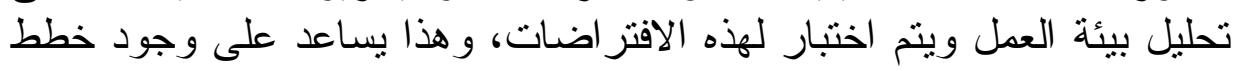

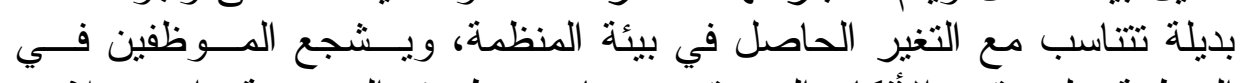

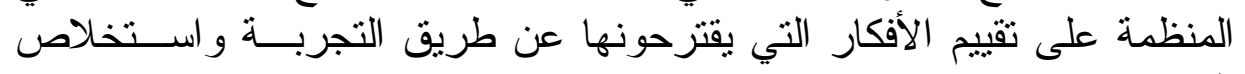
النتائج. - تظهر الدر اسة مستوى مناسباً من الانفتاح على فرص وتجارب جديــدة تبــدو

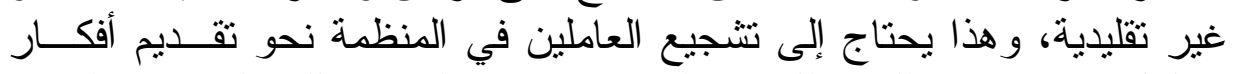
وحلول ابداعية، وكذلك يتطلب إعطاء هامش من المرونة المناع للموظفين في التفكير

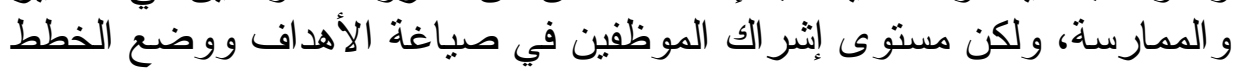


يحتاج إلى تحسين، لأن هذا يعزز من انتماء العاملين من قدرة المنظمة علىى تحقيق أهدافها.

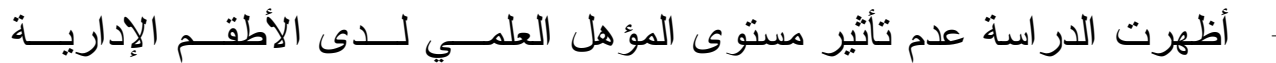

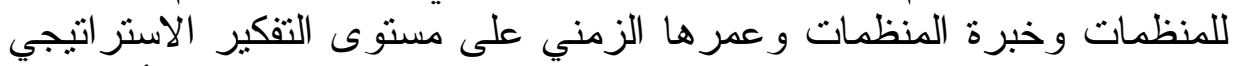

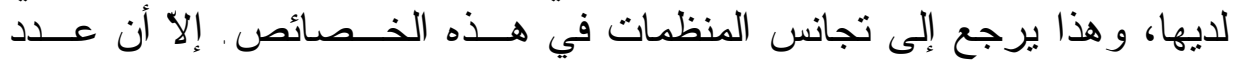

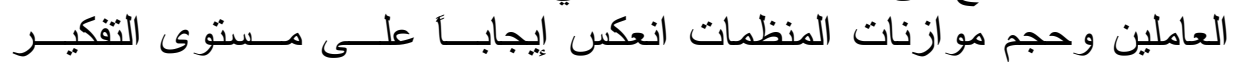
الاستر اتيجي لديها.

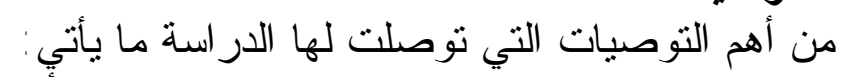

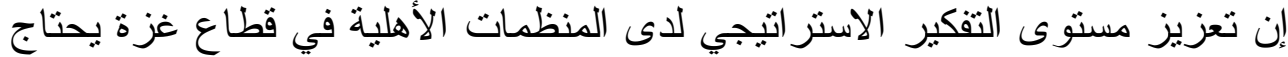

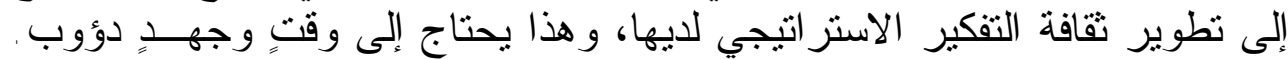

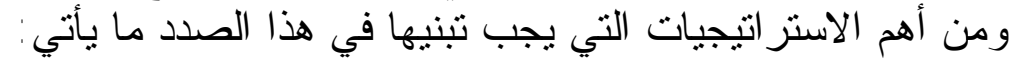

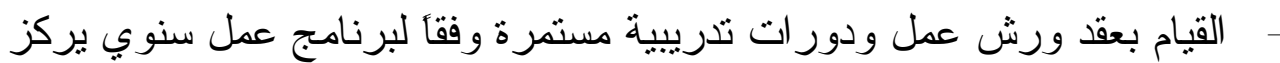

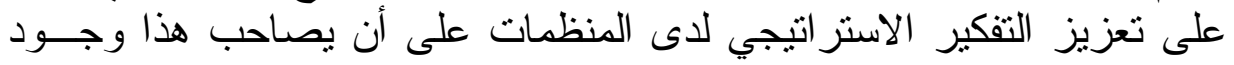

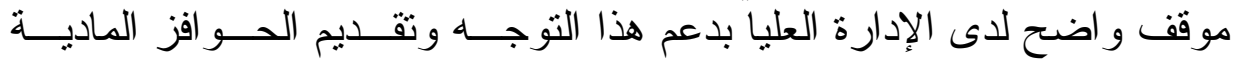

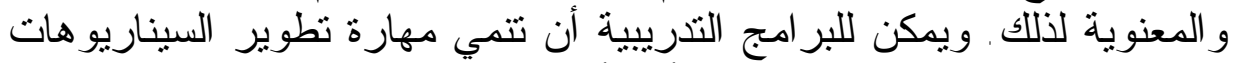

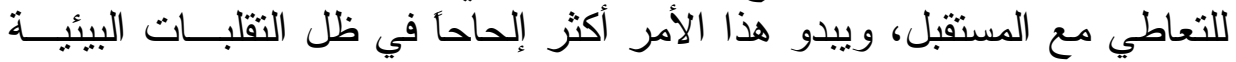

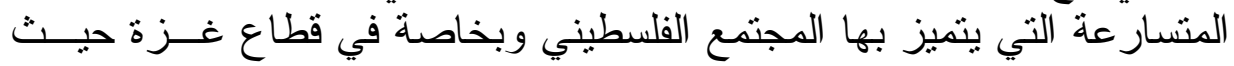
يصعب دقة التنبؤ بالمستقبل .

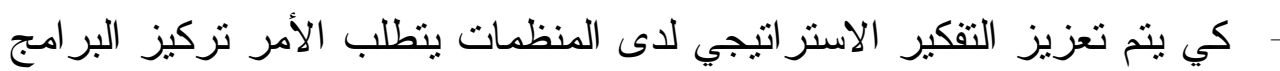

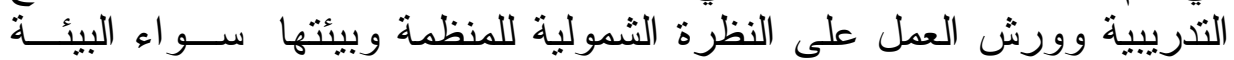

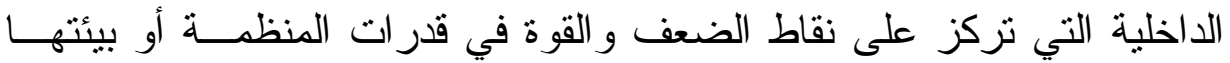

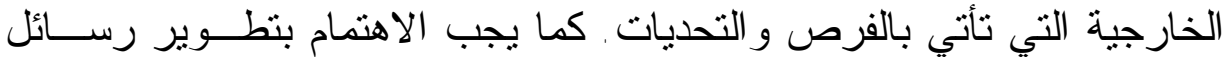

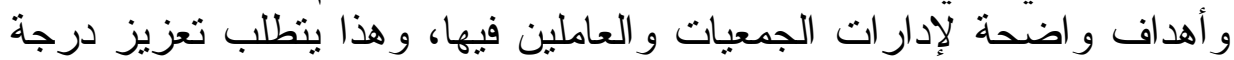

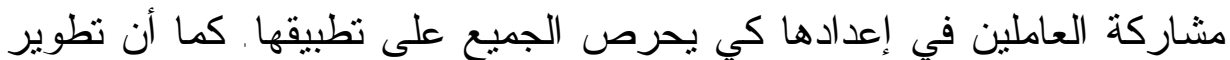

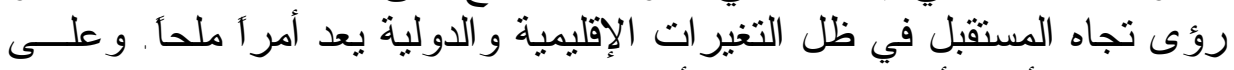

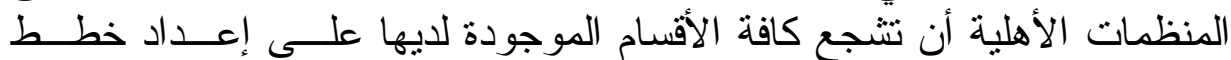

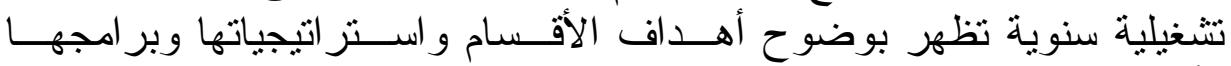

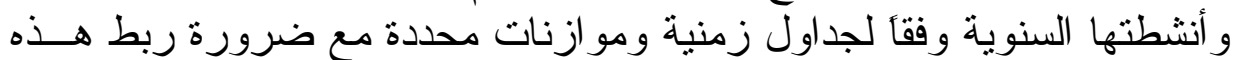

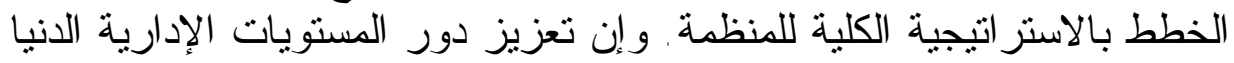

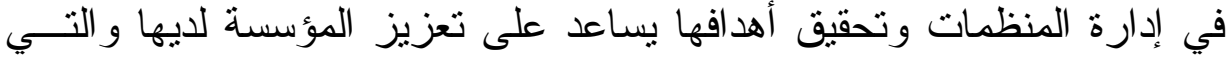

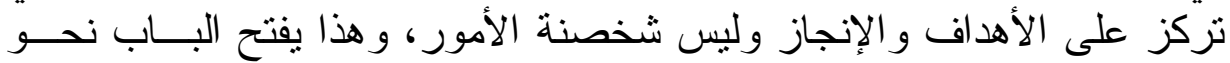
تطوير مستوى الدبادرة و الإبداع و الابتكار لديها. 


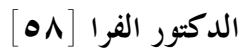

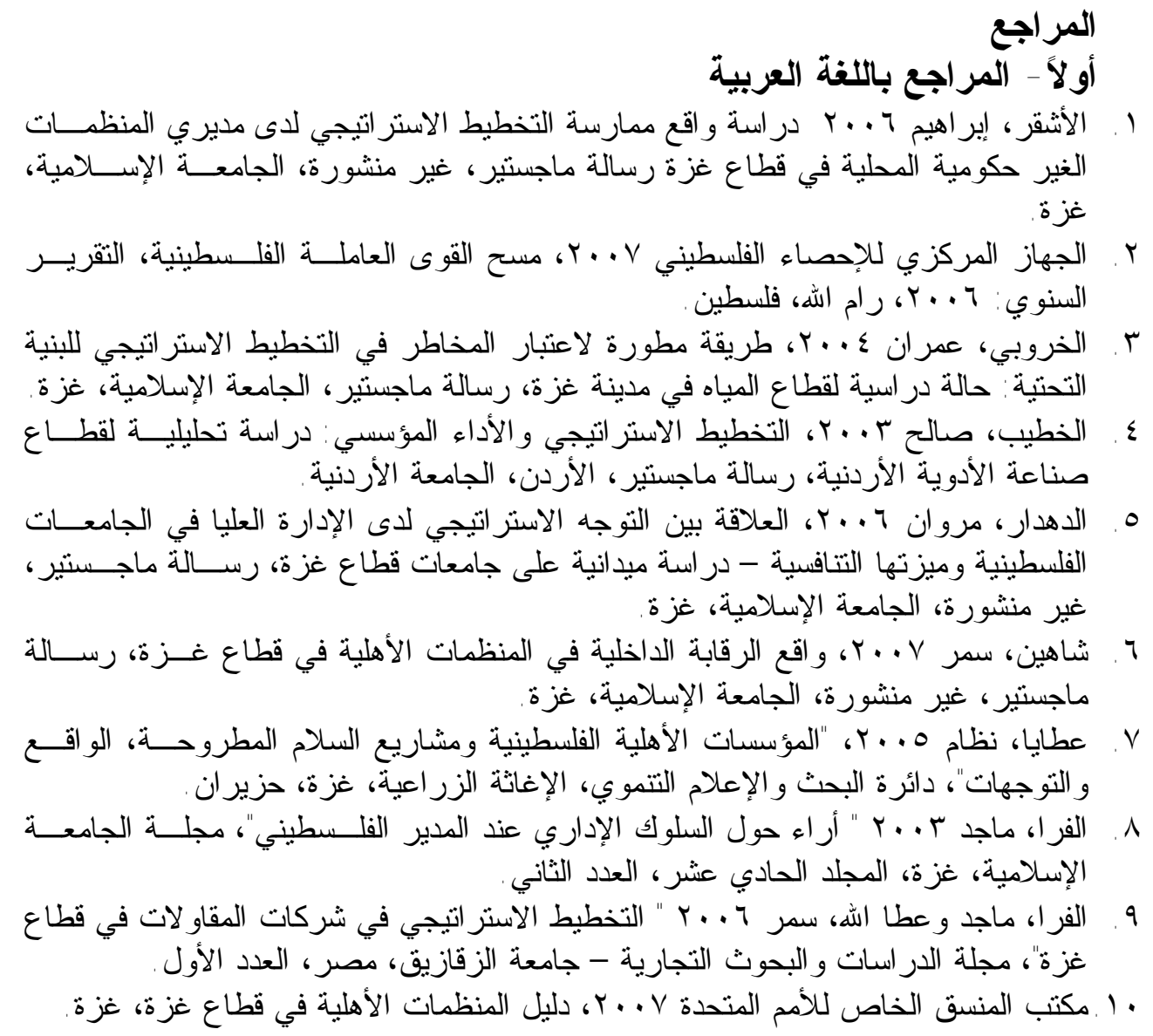

\section{ثانياً - المر اجع باللغة الإجنبية}

1. Abraham S., 2005, "Stretching strategic thinking", Strategy \& Leadership, Vol. 33, No. 5 .

2. Bonn I., 2001, "Developing strategic thinking as a core competency", Management Decision, Vol. 39, No. 1.

3. Bonn I., 2005, "Improving strategic thinking: a multilevel approach" Leadership \& Organization Development Journal, Vol. 26, No. 5.

4. David, Fred, 1999 Strategic Management: Concepts \& Cases, $7^{\text {th }}$.ed., New jersey: Prentice Hall,1999.

5. Garratt, B, 1995 Developing Strategic Thought - Rediscovering the Art of DirectionGiving, McGraw-Hill, London.

6. Ghalayini, Alaa, 2007 The Good Governance Role in the Management and Development of the NGOs in the Gaza Strip from the General Director Perspective, Master Thesis, Unpublished, Islamic University of Gaza.

7. Hannagan, Tim, 1995 Management Concepts \& Practices, London, Pitman Publishing, 1995.

8. Liedtka, J.M. 1998, "Strategic thinking: can it be taught?", Long Range Planning, Vol. 31, No. 1. 
9. MAS 2007 Mapping Palestinian Non-Governmental Organizations in the West Bank and the Gaza Strip, MAS, Palestine.

10. Mintzberg, H., 1994 "The rise and fall of strategic thinking", Harvard Business Review.

11. Nafie, boshra 2006 investigation of the relationship between strategic thinking and innovativeness Of the management at the ministry of health In Gaza Strip Master Thesis, Islamic University of Gaza.

12. Porter, M., 1987 "The state of strategic thinking", The Economist.

13. Thompson, A.A, Strickland A.J, 1999 Strategic Management. Concepts and Cases, $11^{\text {th }}$ ed, Boston, Irwin McGraw-Hill.

14. Wheelen, T., and J. Hunger, 2006 Strategic Management and Business Policy, USA, Prentice Hall.

15. Wilson, 1994 "Strategic planning isn’t dead - it changed", Long Range Planning, Vol. 27,4 . 